\title{
Discussion Paper \\ Federal Student Loan Servicing Accountability and Incentives in Contracts
}

\section{Rajeev Darolia}

University of Kentucky and

Federal Reserve Bank of Philadelphia

Consumer Finance Institute Visiting Scholar

Andrew Sullivan

University of Kentucky

\section{DP 20-05}

October 2020

https://doi.org/10.21799/frbp.dp.2020.05 


\title{
Federal Student Loan Servicing Accountability and Incentives in Contracts
}

\author{
Rajeev Darolia ${ }^{\dagger}$ \\ University of Kentucky and \\ Federal Reserve Bank of Philadelphia Consumer Finance Institute Visiting Scholar \\ Andrew Sullivan \\ University of Kentucky
}

October 2020

\begin{abstract}
Student loan servicers play a critical and underappreciated role in federal student loan programs. The federal government contracts out to servicers an array of many of the most critical functions related to student loan repayment, including account management, payment processing, and the provision of information about payment plans and solutions for distressed borrowers. In fact, most borrowers' interactions with federal student loan repayment are almost exclusively with their servicer. We aim to improve upon the scarce research literature about federal student loan servicers by exploring the complicated set of measures that determine how servicers are compensated for servicing each debtor and awarded portfolios for future business. The coverage and construction of these measures influence servicers' behaviors by creating strong incentives that coincide to varying degrees with the goals of the government, public, student loan borrowers, and the servicers themselves. Understanding accountability and incentives in current and past contracts is critical as the U.S. Department of Education reforms servicer contracts and responsibilities through its Next Gen Federal Student Aid initiative.
\end{abstract}

Keywords: student loans, servicing, government contracts

JEL Classification Codes: H52, I22, I28, L33

\footnotetext{
† University of Kentucky, 427 Patterson Office Tower, Lexington, KY 40506; rajeev.darolia@uky.edu.

¥University of Kentucky, 405 Patterson Office Tower, Lexington, KY 40506; aasu225@uky.edu.
}

Acknowledgments: We are grateful for feedback from Colleen Campbell and Robert Hunt. Darolia received support for the project from the Institute for the Study of Free Enterprise at the University of Kentucky. All errors are our own.

Disclaimer: This Philadelphia Fed working paper represents preliminary research that is being circulated for discussion purposes. The views expressed in these papers are solely those of the authors and do not necessarily reflect the views of the Federal Reserve Bank of Philadelphia or the Federal Reserve System. Any errors or omissions are the responsibility of the authors. No statements here should be treated as legal advice. Philadelphia Fed working papers are free to download at https://philadelphiafed.org/research-and-data/publications/working-papers. 


\section{Introduction}

About 43 million debtors collectively owe more than $\$ 1.4$ trillion in outstanding federal student loan debt in the United States as of 2019, an amount that is nearly three times the amount from 12 years earlier (U.S. Department of Education, 2019). Delinquency rates on student loan debt have nearly doubled during the past decade nationally, and default rates on federal loan programs recently reached their highest level in more than 15 years (Lee et al., 2014; U.S. Department of Education, n.d.). Default and delinquency are costly for debtors, but also for the public; federal student loan debt is guaranteed, such that the public absorbs the costs of default. Student loan servicers (hereafter referred to as servicers) play a critical and underappreciated role in federal student loan programs; the federal government contracts out to servicers many of the most critical functions related to students' loan repayments, including account management, payment processing, and the provision of information about payment plans and solutions for distressed borrowers. In fact, most borrowers' interactions with federal student loan repayment are almost exclusively with their servicer.

In response to growing concerns about servicer practices and efficiency, the U.S. Department of Education (ED) has frequently adjusted the regulatory context for servicers in recent years and has considered numerous drastic programmatic changes, including controversially proposing to move to a single servicer. ${ }^{1}$ Servicer oversight is ever more salient as practices by

\footnotetext{
${ }^{1}$ As part of the overarching agenda to reform student loan servicing, the U.S. Department of Education (ED) announced a plan to consolidate to one student loan servicer in May 2017. Under the plan, Federal Student Aid (FSA) would award one servicing contract, and the chosen servicer could then subcontract out servicing duties to other servicers. The ED argued that having one servicer could increase effective oversight and allow servicers to more efficiently service loans, with the ultimate goal of increasing repayment (U.S. Department of Education, May 19, 2017). After political pushback proposing that having one servicer would place too much risk in the market, the proposed plan changed to having one portal for borrowers to find information on their loans and make payments.
} 
servicers of federally supported student loan debt have increasingly come under fire. For example, high-profile lawsuits have been brought against some of the largest loan servicers: Navient and the Pennsylvania Higher Education Assistance Agency (PHEEA), including by the Consumer Financial Protection Bureau (CFPB) and state attorneys general (e.g., Consumer Finance Protection Bureau, 2017; Cowley, 2017; Hillian, 2019; New York Attorney General, 2019). In addition to lawsuits, consumer complaints about student loan servicing have been prominently highlighted in media reports (e.g., Cowley, 2020; Friedman, 2019; Ortiz, 2019; Rosato, 2017).

The ED has acknowledged limited oversight among its current contracts, asserting that “today's loan servicing environment does not require maximum accountability. The legacy servicing contracts do not contain adequate incentives to reward servicers when they manage borrowers' accounts successfully, and they do not allow for the appropriate consequences to be applied to loan servicers that fail to meet contract requirements" (U.S. Department of Education, 2020). At the end of 2017, the ED announced the Next Gen Federal Student Aid initiative, which intends to alter the nature of how students and their families interact with the federal student aid system. A prominent aspect of this initiative is to reform servicer practices, contracts, and relationships, with its first set of contracts announced in June 2020. Understanding accountability and incentives in current and past contracts is critical as the ED reforms servicer contracts and responsibilities through its Next Gen initiative.

In this paper, we aim to improve upon the scarce research literature about federal student loan servicers. The ED and federal agencies use a variety of accountability mechanisms to provide oversight to servicers, including performance and compliance monitoring, audits, and multiple avenues through which borrowers can lodge complaints. In this paper, we focus on a complicated set of implicit accountability measures that determine how servicers are compensated for servicing 
each debtor and awarded portfolios for future business. The coverage and construction of these measures influence servicers' behaviors by creating strong incentives that coincide to varying degrees with the goals of the government, program administrators, public, student loan borrowers, and the servicers themselves. We also add to the general knowledge of public sector contracting by empirically exploring whether the goals of servicers, borrowers, and the government conflict through this underexplored area.

First, we describe the federal student loan servicing market from 2009 through 2019, a market that has undergone a drastic transformation as student loan borrowing increased substantially, the federal student loan program underwent a large structural change, and the government altered its process for awarding student loan servicing contracts. Next, we examine the implications of the ways that economic incentives in servicing contracts guide servicer behavior, using the lens of performance-based contract theory. The first incentive relates to a perborrower fee paid to servicers with penalties based on delinquency and loan status, which follows a linear contract model (e.g., Heinrich and Choi, 2007). The second incentive derives from how ED semiannually allocates new loans based on the servicers' quarterly performance from the two quarters prior, akin to a multitournament contract (e.g., Gibbons and Roberts, 2013; Holmstrom, 1982). To assess performance as part of this second measure, the ED uses a formula that is currently composed of three components with varying degrees of measurability: default prevention, borrower satisfaction, and federal personnel satisfaction. We examine performance on these metrics over time in relation to national student loan market trends and the relationship of the measures to each other, across servicers, and over time. While connecting servicer goals to public goals can improve performance, these goals may also be in competition with each other. We find repayment measures and borrower satisfaction empirically conflict with each other, which 
gives rise to concerns that increasing success in one may come at the expense of the other. Further, we simulate performance outcomes for servicers under different reweighting schemes that reflect different goal prioritization.

Finally, we consider the extent to which consumer complaints registered against servicers are about terms and fees, handling payments, interactions with servicers and marketing, or account maintenance and information. We code over 16,000 complaints made about federal student loan servicers to the Consumer Finance Protection Bureau (CFPB) from 2016 to 2019 and find that, over the time period, the share of complaints about interactions with servicers and terms and fees have dropped by about half, while the share of complaints related to maintenance and information has doubled.

\section{Federal Student Loan Servicers}

Federal student loan programs account for about $90 \%$ of the over $\$ 100$ billion in student loan funds disbursed in recent years (Baum et al., 2018). Borrowers can access federal loan programs if they attend an eligible institution and if loan approval does not depend on borrower characteristics or expected default risk. Similarly, interest rates in federal student loan programs do not vary with expected default risk and typically have relatively favorable terms: Rates are subsidized, and some federal loan programs offer benefits such as the ability to postpone or reduce payments and/or interest accrual during times of college enrollment or hardship.

Since 2009, the ED has directly funded federal student loan programs with servicing outsourced to nongovernmental contractors. ${ }^{2}$ Servicers play a critical and underappreciated role in

\footnotetext{
${ }^{2}$ Refer to Appendix F for a brief history of federal student loan programs.
} 
the student loan process. Federal student loans are a relatively complex financial instrument that many borrowers will confront at a time when they may lack the knowledge and skills to evaluate. Evidence demonstrates that many students do not know how much they borrow, the terms of their loans, or their future repayment burdens, and more broadly, they are unfamiliar with college financial aid and the costs and benefits of college (Abraham et al., 2019; Akers and Chingos, 2014; Bleemer and Zafar, 2015; Darolia and Harper, 2018; Dynarski and Scott-Clayton, 2006). Upon entering college, borrowers must complete entrance student loan counseling mandated by the ED in order to borrow from federal programs, but it is generally considered ineffective (Fernandez, 2016).

Once students graduate, leave college, or drop below half-time enrollment, interaction with the borrower about student loan repayment largely transitions to the servicer, making the servicer the predominant entity with which most debtors will interface related to repayment. Servicers maintain borrower accounts, collect payments from borrowers, and process requests for deferment, forbearance, and forgiveness. They are also expected to serve as an informational resource to help borrowers navigate among complicated repayment options and solutions to difficulties repaying debt. ${ }^{3}$ Student loan debt repayment is unique in that it is not generally dischargeable in bankruptcy, adding potential burden to debtors who have difficulty repaying their debt and need relief (Darolia and Ritter, 2020).

The modern incarnation of the servicer market started about a decade ago. We display the evolution of the market in Figure 1. Initially, ACS Educational Services/Xerox, serviced federal

\footnotetext{
${ }^{3}$ For example, repayment plans can be confusing; students currently must choose among: "standard" repayment plans (which have fixed payments, typically over 10 years); "graduated" payment plans (in which payments increase on a schedule over the repayment period); "extended" payment plans (that extend the repayment period of standard or graduated plans for up to 25 years); and various income-based repayment plans that vary.
} 
student loans starting in 2004 with a contract for the Common Services for Borrowers solution, including handling the operations of the Direct Loan Program loan portfolio (ACS, 2004; Campbell and Hillman, 2015; O'Flaherty and Battle, 2013). However, the ED through the Ensuring Continued Access to Student Loans Act (ECASLA) of 2008 began buying back Federal Family Education Loan Program (FFELP) loans from holders to provide lenders with liquidity for new loans (Campbell and Hillman, 2015). To service the larger loan volume that would come with ending the FFEL program and this buyback (see Appendix F), the Federal Student Aid (FSA) issued a solicitation for servicers in 2008 under Title IV of Federal Acquisition Regulations (FAR) Part 12 (Campbell and Hillman, 2015; U.S. Department of Education, 2009). ${ }^{4}$ Servicers selected through this solicitation became known as Title IV Additional Servicers (TIVAS), depicted in blue bars in the figure. The initial servicers were FedLoan/PHEAA, Great Lakes, Nelnet, and Sallie Mae. In 2013, ACS's servicing contract was not renewed (Hernandes, 2013). Sallie Mae spun off Navient Corporation in 2014 to become its government student loan servicer, with Sallie Mae servicing private student loans. In 2018, Great Lakes and Nelnet created a joint venture, GreatNet; however, each has continued servicing separately through the end of our analysis period (June 2018), so we consider them separate entities throughout our analysis.

In addition to the TIVAS, FSA also began contracting with not-for-profit servicers (NFPs) following the Health Care and Education Reconciliation Act/Student Aid and Fiscal Responsibility (HCERA/SAFRA) Act of 2010, depicted in green bars in the figure. In September 2011, FSA

\footnotetext{
${ }^{4}$ In the 2008 solicitation to servicers, applicants were evaluated based on the following criteria: (1) experience in processing at least 500,000 loan sale conversions annually and service at least 2,000,000 loans; (2) ability to process at least 500,000 more loan sale conversions annually and service at least 2,000,000 more loans; (3) willingness to improve offeror system; and (4) estimated costs to the government (U.S. Department of Education, 2009).
} 
announced it planned to award servicing accounts to 15 NFP servicers, with accounts eventually awarded to 11 (O'Flaherty and Battle, 2013). When ACS's contract was not renewed in 2013, FSA redistributed ACS's Direct Loan accounts among the NFPs, as well as the TIVAS (Hernandes, 2013; O'Flaherty and Battle, 2013). As a result, NFPs had loans that were more current and mature relative to TIVAS portfolios, making them more stable and less likely than the portfolios of TIVAS to become delinquent (Federal Student Aid, 2015). Last, NFPs began receiving new Direct Loans for the first time in 2015 , collectively receiving $25 \%$ of the new loans from January 1 through August 30 (Hernandes, 2014). Since their original contracts, several NFPs stopped servicing federal loans and transferred loans to other servicers. The largest change among NFPs came in 2013, when Kentucky Student Assistance (KSA) transferred its Direct Loan accounts to Aspire Servicing Center; EdManage, COSTEP, and EDGEucation transferred their accounts to Higher Education Loan Authority of the State of Missouri (MOHELA) (Hernandes, 2013). Aspire then transferred its accounts to MOHELA in 2015. Most recently, the Vermont Student Assistance Corporation (VSAC) cancelled its contract, and FSA transferred its accounts to Nelnet in August 2016 (Brooks, 2016).

The ED has shaped the market through its solicitation and selection process and through ongoing requirements. The initial TIVAS solicitation required potential servicers demonstrate experience in servicing 500,000 loans annually, process an additional 500,000 annually, and enhance servicing systems (U.S. Department of Education, 2009). These requirements created high entrance costs to the market. The NFP solicitation, while having a lower servicing threshold the intent was for each NFP to initially service 100,000 borrower accounts with the potential for additional accounts based on performance — had 64 high-level servicer requirements, including developing interfaces connecting data across various organizations and programs and how to 
manage loans (U.S. Department of Education, 2010). Some NFPs, including COSTEP, EDGEucation, EdManage, and KSA, blamed high infrastructure costs and changing servicing systems for exiting the market (Hernandes, 2013).

As part of the Next Gen initiative, the ED intends to overhaul the way borrowers interact with servicers and the roles that servicers play. The reform was "driven by the experiences of federal student loan borrowers and is responsive to the need to establish a transparent and accountable system that allows for continuous improvement. FSA should continuously evaluate its servicing contracts to ensure that public resources are used efficiently and effectively to promote borrower success and protect taxpayers' investments" (Mitchell, 2016). But the path to reform has been slow and riddled with legal and regulatory challenges, including changes in priorities following the transition from the Obama to the Trump administration (DeVos, 2017), multiple cancelled solicitations, and lawsuits from private collection agencies and existing servicers (see Campbell, 2019, for an overview). In June 2020, the ED announced that it has signed a contract with five servicers for business process operations to directly engage with borrowers through contact centers and to provide back-office processing support, though these awards have also been subject to contention. ${ }^{5}$ Two other solicitations for "enhanced servicing solutions" and "optimal processing solutions" were cancelled, citing inability to reach agreement with vendors (Eidelman, 2020). Because the ED is still in the process of converting to this system and many details of the contracts and responsibilities are still unknown, we focus on the servicing context prior to Next Gen.

\footnotetext{
${ }^{5}$ The companies are Edfinancial Services LLC; F.H. Cann and Associates, Inc.; MAXIMUS Federal Services Inc.; Missouri Higher Education Loan Authority (MOHELA); and Texas Guaranteed Student Loan Corporation (Trellis Company).
} 
We display outstanding federal student loan dollars in repayment by each servicer in Figure 2; we display a corollary figure for the number of borrowers in Appendix Figure A1. Outstanding loan debt data are not available for disaggregated NFPs, so we report them in aggregate. As of the second quarter (Q2) of 2018, the TIVAS serviced about $94 \%$ of outstanding federal student loans dollars in repayment, with PHEAA having the largest market share (34\%), followed by Great Lakes (22), Navient, (21\%), and Nelnet (17\%) (Federal Student Aid, 2018). The remaining 6\% of loan debt is serviced by the NFPs.

In Table 1, we show portfolios by servicer based on 2018 annual and Q1 2019 reports, including private and other loans. Three of four TIVAS also receive revenue from non-federal loan servicing, although at a much smaller magnitude compared with federal loan servicing. MOHELA services more in federal loan dollar and borrower volume than the other NFPs combined but still much less than any for-profit servicer.

\section{Compensation per Borrower Schedule}

Given the importance of servicers in collecting student loans and providing information to borrowers, the ED uses two primary economic mechanisms for guiding servicer practice. The first pays servicers a set per-borrower amount monthly that varies by the repayment status and classification of the borrower. For borrowers in repayment, payments are graduated based on a borrower's delinquency, as shown in Figure 3, similar to a linear contract (e.g., Gibbons and Roberts, 2013; Heinrich and Choi, 2007). Consider profit for servicer $j$ per borrower $i$ in period $t$, $\Gamma_{j i t}:$

$$
\Gamma_{j i t}=S_{t}-P_{1 t}\left(D_{j i t}\right)-P_{2 t}\left(G_{j i t}\right)-C_{j i t} .
$$


For each borrower serviced, servicers obtain revenue equal to the base rate of compensation available to all servicers and set by the $\mathrm{ED}, S_{t} . S_{t}$ is discounted by a per-borrower rate, $P_{1 t}$, that is a function of the number of days a borrower is delinquent, $D_{j i t}$, or a per-borrower rate, $P_{2 t}$, that varies by the classification of the borrower, $G_{j i t}$. The servicer's per-borrower servicing costs, $C_{j i t}$, are further subtracted from revenue.

Under the current formula, a servicer receives a base rate of $\$ 2.85$ per borrower in repayment. The payment is discounted according to a piecewise penalty function, where:

$$
P_{1 t}=\left\{\begin{array}{ccc}
0.00 & \text { if } & D_{j i t} \leq 5 \text { days } \\
0.74 & \text { if } & 6 \text { days } \leq D_{j i t} \leq 30 \text { days } \\
1.39 & \text { if } & 31 \text { days } \leq D_{j i t} \leq 90 \text { days } \\
1.50 & \text { if } & 91 \text { days } \leq D_{j i t} \leq 150 \text { days } \\
1.62 & \text { if } & 151 \text { days } \leq D_{j i t} \leq 270 \text { days } \\
2.40 & \text { if } & D_{j i t}>270 \text { days }
\end{array}\right.
$$

In other words, there is no penalty if the borrower is current (i.e., they are servicing their obligations on time, a $\$ 0.74$ penalty if the borrower is $6-30$ days delinquent, and up to a $\$ 2.40$ penalty for borrowers more than 270 days delinquent). ${ }^{6}$ This lever directly correlates servicers' revenue generation goals with the goal of default prevention as servicers earn higher revenue by keeping borrowers current. Penalizing servicers as delinquency days increase provides an incentive for revenue maximizing servicers to keep their borrowers current on payments.

In a similar fashion, revenue per borrower is discounted by the classification of the borrower. Debtors who are actively servicing or expected to service their loan are considered in

\footnotetext{
${ }^{6}$ Compensation changed in 2014 from the initial 2009 contract to increase the delinquency penalty. For example, from 2009 to 2013, the penalty associated with a severely delinquent account (i.e., $>270$ days late) was $76 \%$ of the base rate of compensation, whereas currently the penalty is 84 . Moreover, the delinquency penalty previously did not begin until a borrower was more than 30 days late on payments, as opposed to the current five-day threshold. Historical rates are shown in Appendix B.
} 
repayment. Alternatively a borrower can be in a grace period, which is typically a six-month period between separating from school and the time when payments begin; deferment, which is a granted temporary stop to payments for which interest may not accrue for certain loan programs; forbearance, which is a granted temporary stop to payments for which interest accrues; or still in school. There is also a special category for service members that results in servicers being compensated at the base rate of compensation. ${ }^{7}$

$$
P_{2 t}=\left\{\begin{array}{ccc}
0.00 & \text { if } & G_{j i t}=\text { In Repayment } \\
0.00 & \text { if } & G_{j i t}=\text { Service Member } \\
0.74 & \text { if } & G_{j i t}=\text { Grace Period } \\
1.17 & \text { if } & G_{j i t}=\text { Deferment } \\
1.80 & \text { if } & G_{j i t}=\text { Forbearance } \\
1.80 & \text { if } & G_{j i t}=\text { In School }
\end{array} .\right.
$$

Since borrowers in a grace period, deferment, forbearance, and in school are not actively repaying, they cannot be delinquent, and thus, $P_{1 t}$ will always be equal to zero for these debtors. This then creates the incentive to keep a borrower actively in repayment, but it also provides an incentive for the servicer to help the student apply for a deferment or forbearance if the borrower is already or at risk of becoming severely delinquent.

Such an incentive-based payment scheme implicitly assumes that servicers can affect debtors' repayment status. In our model, a servicer can decrease delinquencies or move them to a different status by expending more to service the borrower, which can vary across servicers and borrowers. Factors outside of a servicer's control can also affect repayment status and classification, following contract theory (Gibbons and Roberts, 2013). Thus, we can think of

\footnotetext{
${ }^{7}$ According to the 2014 TIVAS contract, a servicer still receives full funding for delinquent service members, although servicers must document actions taken to prevent delinquency. A service member more than 300 days delinquent may be placed in forbearance by FSA to prevent the borrower from going to debt collection.
} 
borrowers' repayment status and classification as functions of borrower servicing costs, $C_{j i t}$, economic conditions affecting all borrowers in a period, $\theta_{t}$, and idiosyncratic borrower characteristics, $\varepsilon_{i}$ :

$$
\begin{aligned}
& D_{j i t}=f\left(C_{j i t}, \theta_{t}, \varepsilon_{i}\right) \\
& G_{j i t}=f\left(C_{j i t}, \theta_{t}, \varepsilon_{i}\right) .
\end{aligned}
$$

The per-borrower compensation system is likely to guide servicer behavior, and it potentially creates competition among a servicers' goal to maximize revenue and goals of the government and borrowers, such as paying off the loan quickly or reducing the burden on borrowers. For example, a servicer has the incentive to keep borrowers current on their loans because they get higher compensation as the number of days of delinquency decrease. But a singular focus on delinquency may have negative consequences for debtor welfare; for example, consumer groups have sued Navient claiming that the firm makes excessive and aggressive calls to borrowers, while Navient claims that such calls can help borrowers avoid default (Ortiz, 2019).

The compensation schedule also provides an incentive for servicers to prefer certain classifications over others. For example, a servicer receives a lower payment for a borrower in forbearance than for a borrower in repayment with up to 270 days of delinquency but a higher payment for forbearance than a borrower behind on payments greater than 270 days. Moreover, potentially differential costs associated with the various activities needed to service borrowers have the potential to drive behavior. For example, Navient and Great Lakes were accused of steering borrowers into forbearance because this action cost the servicer less than alternatives that might better improve borrower welfare (Congressional Research Service, 2019). 
Moreover, the compensation schedule provides incentives to servicers related to how long borrowers stay in repayment. Consider that total profit for servicer $j$ in period $t$ is the sum of profit from all individual borrowers serviced:

$$
\Gamma_{j t}=\sum_{i=1}^{N t} \Gamma_{j i t},
$$

where the number of borrows in period $t$ is all borrowers allocated to a servicer in prior periods, $N_{j t}^{\eta}$, minus the borrowers who no longer have debt repayment responsibilities, $N_{j t}^{\tau}$, because they have paid off their loans or have had debt forgiven, for example:

$$
N_{j t}=\sum_{t=-1}^{-T}\left(N_{j t}^{\eta}-N_{j t}^{\tau}\right)
$$

Servicer revenue declines as borrowers pay of their loans or have debt forgiven under the perborrower compensation schedule, and therefore, servicers have the incentive to maximize the number of borrowers who remain in their portfolios while keeping them current.

\section{Future Allocations}

The government's second economic lever rewards performance by modifying allocations of awarded loan portfolios based on performance. This second lever incorporates some of the other goals that are not addressed by the per-borrower compensation schedule, such as borrower satisfaction. In Figure 4, we display the proportion of new borrowers allocated to each servicer (unlike the data on outstanding data portfolios, we have data on new allocations for each NFP). Servicers vary in their allocations, with PHEAA consistently receiving a small percentage of new allocations and Great Lakes and MOHELA receiving the largest. After quickly increasing through Q2 2015 from about 25\% to 70\%, NFPs as a group decreased in its share over time until 2018, 
with Great Lakes being the main beneficiary, although NFPs have begun increasing in its share in recent quarters.

The ED awards future allocations following a multitournament framework where servicers are rewarded based on rankings over multiple points in time (Gibbons and Roberts, 2013). Each servicer earns points each period based on a set of metrics we describe next. Each servicer's new allocations in a period are directly proportional to its share of points earned relative to total points available in each period across all servicers. ${ }^{8}$ Servicers earn points based on a relative ranking within each metric, with the highest ranked servicer earnings points equal to the total number of servicers, the second best equal to the total number minus one, and so on (Federal Student Aid, 2017). There have been nine servicers including both TIVAS and NFPs competing in the tournament since 2016, so in recent years, the top ranked servicer in a given measure would earn nine points, the second best would earn eight points, and so on, and the worst ranked servicer would earn one point.

\subsection{Measures Used in Allocation Formula}

${ }^{8}$ Specifically, servicer $j$ 's new allocations in period $t, N_{j t}^{\eta}$, are directly proportional to its share of points earned each period, $\Phi_{j t}$ relative to total points available in each period across $J$ servicers: $\frac{N_{j t}^{\eta}}{\sum_{j=1}^{J} N_{j t}^{\eta}}=\frac{\Phi_{j t}}{\sum_{j=1}^{J} \Phi_{j t}}$.

The maximum and minimum shares of new borrowers a servicer can gain in a period are:

$$
\begin{aligned}
& \text { Maximum Share }=\frac{2}{J+1} \\
& \text { Minimum Share }=\frac{2}{J(J+1)} .
\end{aligned}
$$

There have been nine servicers competing in the tournament since 2016, meaning that servicers can have at most $20 \%$ of new allocations and $2 \%$ of new allocations at minimum. 
There are three general categories of metrics on which servicers are ranked, displayed in Table 2: repayment status (weighted at $60 \%$ of the total score), borrower satisfaction $(35 \%)$, and federal personnel satisfaction $(5 \%)$. The three general categories are further stratified, based on characteristics of borrowers, such as delinquency and years from graduation, described in more detail in the next section. Servicers receive points in each metric which are then weighted by $\omega$. We show weights in the far right column of Table $2 .{ }^{9}$ A servicer's allocation can be increased by improving its rank in any metric, meaning servicers may then decide among goals to prioritize and that the weights ED assigns to categories and metrics are likely to affect servicers' investment in servicing borrowers in one category relative to others.

First, consider the default prevention metrics, for which there are multiple components. A debtor in repayment can be in one of four mutually exclusive delinquency categories, based on their number of days delinquent, as determined at the end of each quarter (a debtor in default is not considered to be in repayment): ${ }^{10}$

1. Not more than five days late on payments (ED calls this group Current);

2. Payments 6-90 days late (We deem this group as Minor delinquency);

3. Payments $91-270$ days late (We deem this group as Moderate delinquency);

4. Payments 271-360 days late (We deem this group as Severe delinquency).

\footnotetext{
${ }^{9}$ These metrics have been in effect since 2014. The metrics from pre-2014 are included in Appendix C. The four major changes were: (1) FSA made allocations semiannually instead of annually; (2) FSA no longer used school surveys; (3) the metrics related to repayment status/default prevention were changed; and (4) weights were changed. Through this, it redefined how it measured default prevention, while implicitly weighting certain goals. Borrower satisfaction and default prevention increased in relative importance, while federal and school satisfactions drastically decreased.

${ }^{10}$ From Navient's 2014 contract: "For metrics I, 2, and 3 borrowers in school, in grace, in deferment, in forbearance, in Service Member, and over 360 days delinquent are excluded from both the numerator and denominator in the calculations. Calculations will be rounded to the hundredth of a percent. Borrowers with loans in multiple statuses shall be counted once, in the lowest performing deliverable status. The lowest performing deliverable status is defined as the lowest unit priced deliverable" (Navient, 2014).
} 
Using these categories, the ED calculates three measures for each servicer: percent current $\left(\frac{\# \text { Current }}{\# \text { In Repayment }}\right)$, percent moderately delinquent $\left(\frac{\# \text { Moderate Delinquency }}{\# \text { In Repayment }}\right)$, and percent severely delinquent $\left(\frac{\# \text { Severe Delinquency }}{\# \text { In Repayment }}\right)$. The proportion of the servicing pool with minor delinquency is not captured in the data but can be inferred as the remaining borrowers in repayment. ED follows the ranking steps for each of these three metrics within the repayment allocation ranking, where percent current receives the highest weight, $30 \%$ of the total, while moderate and severe delinquency are each weighted at $15 \%$ of the total.

Borrowers have been further stratified within the repayment status measure into five segments since Q1 2016: (1) borrowers with at least one Consolidation or Parent PLUS loan; (2) borrowers who graduated within the past three years; (3) borrowers who graduated more than three years ago; (4) borrowers who did not graduate and left school within the past three years; and (5) borrowers who did not graduate and left school more than three years ago. The repayment metric is split into these five segments as the risk of delinquency varies by student characteristics and servicer portfolios differ in their makeup of students. For example, if a servicer had a high proportion of borrowers in a high-delinquency segment, it would seem to perform worse than others, on average, without special consideration. Further, segmenting borrowers increases the connection between servicers' actions and repayment rates as more is within control by considering characteristics of the borrowers, reducing the influence on rankings of borrower characteristics (Rubenstein et al., 2003). Ranking servicers within each segment by repayment metric and quarter also help ensure that servicers are held accountable for actions within their control, without penalizing servicers for things like economic and labor market trends (Holmstrom, 1982). We display weights for the stratified segments in Appendix Table C1. 
The second measure reflects borrowers' subjective evaluations of their respective servicer and is weighted at $35 \%$. The survey is based on the American Customer Satisfaction Index methodology, which is used to measure satisfaction in a variety of industries. According to documentation, scores can range from a minimum of zero to a maximum of 100, with a national average across all industries of $76 .{ }^{11}$ To try to make borrower surveys comparable across servicers, borrower satisfaction survey scores are calculated separately by loan status (in repayment and current, in repayment and delinquent, in grace period, and in school). In the survey, borrowers are asked questions related to customer service, quality of information, and ease of processes (Federal Student Aid, 2017). Borrowers likely value factors other than just being current on payments, including having access to flexible repayment options and servicer responsiveness; therefore, using the borrower survey provides incentives for servicers to meet these other goals. However, borrower goals are idiosyncratic and not fully known to servicers, reducing outcome measurability and possibly servicers' ability to achieve high satisfaction even with proper incentives, particularly relative to repayment rates (Lu, 2015). Factors common to all servicers such as national attitudes toward loan servicing or student loan policies more generally could also influence borrower satisfaction, particularly as survey are not necessarily based on interactions with servicers.

Last, the federal professional survey asks FSA staff about their satisfaction of each servicer from 0 to 100 , where 100 is a perfect score. Questions are similar to the borrower survey as well as about the servicer's data system, work products, information received, and general working relationship with the servicer (Office of Inspector General, 2019). Publicly available information

\footnotetext{
${ }^{11}$ See, for example Federal Student Aid, (2015) and https://www.theacsi.org/. Additionally, the response rate is low, about 3\% or 4\% in 2017 (Office of Inspector General, 2019).
} 
on this measure is scarce, and this measure was downweighted from $20 \%$ to $5 \%$ when ED revised the allocation methodology in 2014.

\subsection{Trends in Performance on Measures Used in Allocations}

In Figure 5, we show the national performance trend for measures used to allocate borrowers to servicers from Q3 2014 (the first quarter of the current incarnation of the allocation metrics) to Q2 2018 (the end of our analysis period), with each servicer weighted based on its amount of loans outstanding as of $2018 .{ }^{12}$ First, consider the repayment rates in panel A. About $70 \%$ to $80 \%$ of borrowers in repayment are current, depicted in the solid red line, with a slight trend upward. This increase in current borrowers largely seems to have come from a decrease in the proportion of borrowers with minor delinquency ( 6 to 90 days delinquent, dotted orange dashed line), as percent moderately (91-270 days, green line) and severely (271-360 days, blue long-dashed line) delinquent have remained relatively flat. ${ }^{13}$

We display current repayment trends by servicer in Figure 6 (we display trends in other measures of repayment status in Appendix Figure A3). First, in Figure 6, panel A, we show that TIVAS servicers have a growing proportion of borrowers that are current on payments over time. Great Lakes consistently has the highest rate of current repayment throughout the period, while

\footnotetext{
${ }^{12}$ Information on the number of borrowers for each segment by servicer is not publicly available. After Q1 2016, we also weight repayment rate by the number of borrowers in each segment overall, described in detail in Appendix E.

${ }^{13}$ Repayment rates differ by borrower segment, as shown in Appendix Figure A2. Although the percent of borrowers current has stayed mostly flat or increased slightly within each segment, a large discrepancy exists in repayment rates across segments, with borrowers leaving school without graduating in the past three years averaging about 30 percentage points lower than borrowers graduating or with a consolidation for Parent PLUS loan in the top panel. The second panel shows the percent of borrowers severely delinquent. Borrowers more than three years removed from school severely delinquent have decreased since 1st Q 2016, whereas others have similar levels. While levels are different and percentage current has increased less than the rates reported by FSA quarterly reports, the Federal Reserve Bank of New York Consumer Credit Panel data on percentage of borrowers in repayment that is current has also increased by $3.5 \%$ between 2014 and 2017 .
} 
rates of current repayment increased by more than 10 percentage points for Navient and Nelnet. NFP servicers' current repayment rates shown in Figure 6, panel B, decreased notably until late 2015, close to when FSA converted to rewarding performance for each segment of borrowers (recall that NFPs were originally assigned portfolios that were relatively mature and less likely to become delinquent). NFP servicers have trended upward since, converging and following a similar pattern with TIVAS servicers. While a bigger discrepancy existed for repayment rates between TIVAS and NFP before 2016, little exists now, although variation still exists across all servicers.

Nationally, performance on the borrower survey, shown in Figure 5, panel B with a solid, purple line, declined 12\% between Q2 2015 and Q3 2015, but stayed relatively flat thereafter. FSA stated the decrease was due to a change from live telephone interviews to online surveys distributed through email - where respondents felt less social pressure to provide positive responses - and similar in magnitude to decreases in other industry surveys when making the method change (Federal Student Aid, 2015). In Figure 7, panel A, we see that Great Lakes and Nelnet have received relatively high ratings from borrowers and decreased relatively less ( $2 \%$ and $7 \%$, respectively) since Q3 2014. PHEAA's and Navient's ratings decreased about $12 \%$ and $15 \%$, respectively, over the same period, with a notable dip around the time the survey collection method changed. NFP servicers saw a decrease in satisfaction in 2015, as shown in Figure 6, panel B, similar to the TIVAS, but are flat thereafter.

Nationally, the federal personnel survey trend has slightly increased over time (Figure 5, panel B). Federal personnel surveys by servicer are displayed in Appendix Figure A4 and show most servicers have increased their scores since Q3 2014, though this measure exhibits greater variation from period to period for each servicer. 


\section{Simulations Using Alternative Goal Weights}

To explore how the weights that reflect different goal prioritizations result in different types of allocations, we next perform two sets of simulations. First, we equally weight the five primary measures currently used (i.e., we weight percent current, percent moderately delinquent, percent severely delinquent, borrower survey, and federal personnel survey at $20 \%$ each). Second, we consider a scheme in which only one of the metrics is used (i.e., with a weight of $100 \%) .{ }^{14}$ Whereas equal weights imply each goal has equal value, an extreme weight implies that the goal is the only one valued. As we show next, the differences among simulated results shows that FSA's weights affect servicer loan portfolios.

We perform these reweighting scenarios for each quarter from Q1 2016 through Q2 2018, and then present the average across those quarters in Figure 8. First, consider panel A, with the current performance system on the left and the equal weighting simulation on the right. Each segment in the simulated allocation is the average new allocations based on a weighting system, with TIVAS servicers in shades of blue and NFPs in shades of green. Bars are capped at 100\%, meaning each bar segment shows the average allocation for a given servicer under a given weighting scheme. Little change exists when comparing equal weight simulations to true allocations. Effectively, this is because the repayment measures have the same average weights ( $20 \%$ each) in the current system and the equal weighting simulation, so the main change is moving 15 percentage points of weight from the borrower survey to the federal survey. As a servicer's

\footnotetext{
${ }^{14}$ As described in Appendix E, for this exercise, we need to estimate the number of borrowers in each segment and delinquency status as these data are not publicly available. Using data on borrower type from FSA's "Direct Loan Portfolio by Delinquency Status and Enrollment" documents (Federal Student Aid, 2018a), we divide borrowers into segments and repayment status and follow the ranking and weighting point system for allocating new loans described previously. The correlation between true and estimated allocations is about $98 \%$.
} 
relative rank in both changed little over time (as shown in Figure 7 and Appendix Figure A4), this has little effect on the allocations.

Simulations using extreme weights in panel B show larger changes in the allocations servicers would receive, especially when borrower and federal personnel survey rates are weighted more heavily than repayment rates. For example, if allocations were made solely on the basis of the borrower survey, the NFPs would receive a smaller share, about $55 \%$ of allocations, as compared with just over $60 \%$ in the current scheme or over $70 \%$ in a simulation in which only severe delinquency matters. The benefit associated with only using the borrower survey would largely benefit Great Lakes, Nelnet, and Granite State. On the other hand, Cornerstone and Navient would receive their smallest shares of allocations in a scenario that heavily values the borrower survey. Last, although a sole focus on the federal survey produces similar outcomes as the borrower survey for some servicers such as Great Lakes and Nelnet, it produces similar results as the present weighting scheme for others, most notably Navient. Overall, these simulations imply what FSA values, and thus weights in determining allocations, can alter the revenue of servicers and their behavior.

\section{Relationships Among Measures Used in Allocations}

We next analyze how the three categories of measures used within the allocation formulas default prevention, borrower satisfaction, and federal personnel satisfaction — relate to each other. We would not always expect for good servicer performance on one factor to correspond to higher performance on another factor, and, in fact, may be in conflict, as suggested by the simulations. For example, as previously mentioned, Navient claims that frequent contact with borrowers can help borrowers avoid default (Ortiz, 2019); however, "Keep getting calls about my loans" is a 
common complaint made against servicers (see discussion of complaints database in the following section). Thus, borrower satisfaction surveys and repayment rate measures may be negatively correlated.

Consider the relationship between current repayment status and the borrower and federal surveys, as displayed in Figure 9. For simplicity, we use current repayment as our primary measure of the repayment status, plotted on the $\mathrm{X}$-axis (we include corollary figures for moderate and severe delinquency in Appendix Figure A5). Each marker represents the relationship between the proportion current and either the borrower survey (circle marker, fit with a solid linear line) or federal personnel survey (diamond marker, fit with a dashed line) for each quarter from Q3 2014 through Q2 2018 and weighted by servicer loan volume. Borrower satisfaction and proportion of borrowers who are current on their student loan repayment obligations have a negative relationship, suggesting that actions that bring borrowers current on their payments may not be appreciated by borrowers. The federal survey has a positive relationship with current repayment status, suggesting an opposite relationship. Goals of federal personnel may then instead be more directly aligned with keeping borrowers current.

In Appendix Figure A6, we see that these relationships still mostly hold among the TIVAS when broken out by servicer (panels A and B). However, NFPs mostly have a flat or slightly positive relationship between current repayment and the borrower survey and a flat or slightly negative relationship between repayment and the federal personnel survey (panels C and D). This could also be a function of NFP servicers having portfolios that include relatively more borrowers who are current on their payments.

We next estimate repayment (percent of borrowers who are current in the top panel or severely delinquent in the bottom panel) as a function of borrower or federal survey score using 
linear regression and present results in Table 3. We include calendar quarter-year fixed effects to control for any unobserved characteristics affecting all servicers in each quarter, such as the national economy, and servicer fixed effects to account for any unobserved, time-invariant characteristics of servicers. We weight by the servicer's share of total loan dollars outstanding.

Results are consistent with Figure 9. On average, a servicer's scoring a percentage point higher on the borrower survey is related to a decrease in share of borrowers who are current by about 0.61 to 0.67 percentage points in columns 1 and 3 . The point estimate for the federal survey is positive, consistent with Figure 9, but not estimated with precision. These results provide further evidence for potentially conflicting default prevention and borrower satisfaction goals, in that on average a servicer does more poorly on its current repayment rate during periods when their borrower survey score is higher.

\section{Consumer Complaints}

To dig into the nature of borrower satisfaction, we next explore complaints made against servicers. We use complaints data from the Consumer Finance Protection Bureau (CFPB), which maintains a repository for complaints reported to the CFPB.${ }^{15}$ To make a complaint on the CFPB website, a borrower checks boxes describing the product (e.g., federal student loan) and the type of problem and subissue (e.g., "Problem lowering your monthly payments"), while also naming the offending company. They are also given the opportunity to describe the issue through a narrative and provide a suggestion for a fair resolution. Such complaints and narratives are not verified by the CFPB

\footnotetext{
${ }^{15}$ The CFPB was created in 2010 as part of the Dodd-Frank Wall Street Reform and Consumer Protection Act and exerts authority to oversee student loan servicers through its oversight of prominent participants in student loan markets.
} 
before becoming publicly available, leading some to question their veracity (e.g., Delisle and West, 2019); nonetheless, the complaints are informative since they are one of the public data elements that reflect borrowers' dissatisfaction and can provide insight into borrowers' perceptions and attitudes.

From mid-2014 to July 2019, roughly 32,000 complaints about student loan servicing were registered in the CFPB repository. Prior to January 2016, borrowers were not asked to identify whether their complaints were related to federal, nonfederal, or private student loans. We therefore focus our analysis on complaints made about the TIVAS and NFPs related to federal student loan servicing between January 2016 and July 2019, which total roughly 16,500 complaints. The exercise is similar in spirit to the report by Delisle and West (2019), who considered a sample of 1,200 complaints made under the federal loan servicing category. Asserting concerns that borrowers may mischaracterize their complaints, those authors ignore how borrowers themselves categorize complaints and use the lens of their staff and consultants to interpret borrower narratives. In our exercise, we instead consider roughly 16,500 student loan complaints made about the TIVAS and NFPs available in the database and rely on the borrowers' own interpretation of their experiences. Because students may hold a combination of federal, non-federal, or private student loans, but choose only one category under which to register grievances, and because evidence suggests that students sometimes do not fully understand the type of loan they hold (e.g., Darolia and Harper, 2018), we also conduct supplementary analysis of complaints made about all types of loan servicing (federal, nonfederal, and private). Conclusions are similar when we use the full sample of all as when we restrict to just federal loans, as shown in Appendix Figures A7 and A8. 
In Figure 10, panel A, we plot the trends over time in total complaints and total complaints per million borrowers in repayment by quarter for all servicers. Most quarters have about 600 to 1,500 complaints and 200 to 400 complaints per million borrowers, with a slight trend upward. There is a large spike in the first quarter of 2017, coinciding with several state attorney generals' suing Navient. We proffer no opinion here about the merits of the lawsuits, but instead consider if they highlighted complaints about Navient that could have influenced borrowers' and policymakers' perceptions. Navient had by far the largest percentage of complaints in the CFPB database and accounts for about half of all complaints. In panel B of Figure 10, we split out Navient and PHEAA from the rest of the servicers as the two servicers with the most complaints over the time period (about 8,000 or half of all complaints and 2,500 or one-eighth of all complaints, respectively). Navient's complaints per million borrowers increased over 1,500\% during early 2017 lawsuits, though it is unclear if the underlying dissatisfaction was in response to or a precursor to the high-profile lawsuits brought against the company. PHEAA's complaints patterns slightly increased during the time period and spiked (about a 100\% increase) correspondent to prominent legal actions against them, such as that brought by the Attorney General of Massachusetts in 2017 (Cowley, 2017), though at a much smaller magnitude compared with the complaints related to Navient. Other servicers, in total, did not see much change in the rate of complaints around the time of the Navient spike.

We next explore to which aspects of borrowing complaints relate to each other. Recent lawsuits demonstrate borrowers' dissatisfaction related to things like harassing calls, being unknowingly moved into forbearance, frustration with inability to get loans forgiven, and inflexibility in payment options. However, the context around student loan repayment is complicated, and responsibility for various aspects of dissatisfaction may be distributed among 
parties beyond the servicer. For example, debtors might be dissatisfied with their loan repayment experience if they do not believe that their education was "worth it," even though this is likely to be largely a function of their educational and labor market experiences. Alternatively, a debtor might be unhappy with their interest rate, which are largely determined by the federal government. Servicers are the main point of contact for borrowers in repayment and thus may be the target of borrowers' ire, regardless of the servicers' power to remediate the specific grievance. Coding complaints by issue category provides insight into borrowers' perceptions and dissatisfaction with various aspects of the student loan experience, beyond just actions by the servicer.

We code each complaint as one of four categories: terms and fees; payment handling; marketing practices and interactions with servicers; and account maintenance and information (see Appendix D for details). For example, we consider a complaint to be related to handling payments when a debtor says they have "Trouble with how payments are handled" or "Can't get flexible payment options for repaying your loan." Examples of subissues we code as related to interactions with servicers when they "Keep getting calls about my/your loans" and "Problem with customer service." When students say that they "Received bad information about my/your loan" or "Need information about my/your loan balance/terms," we code these subissues as related to account maintenance and information. Finally, complaints about terms and fees include subissues like "Don't agree with fees charged" and "Problem with the interest rate." We also reviewed the complaint narratives to inform our classification process and provide the full list of subissues and some illustrative examples of narratives in Appendix D.

We see in Figure 11 that the share of complaints related to maintenance and information is growing over time. About $20 \%$ of complaints were about account maintenance and information in Q1 2016; this share rose to over 40\% by Q2 2019. Meanwhile, complaints related to handling 
payments initially increased from 43\% to 55\% from Q1 2016 through Q1 2017 but has since decreased back to close to $40 \%$. Last, the share of complaints about interactions with servicers or marketing dropped from $20 \%$ to $10 \%$ around Q1 2017, and the share about terms and fees has fallen from $12 \%$ to about $6 \%$ over the timespan.

These trends suggest that borrowers may be less satisfied, particularly with aspects of borrowing related to account maintenance and information, such as receiving information about their loans. In terms of economic incentives, FSA does not directly consider CFPB complaints in how servicers are compensated or allocated new loans. It is possible that the concerns underlying the complaints database are reflected in the borrow survey; however, the shift in CFPB complaint categories does not seem to relate to the borrower survey overall ratings which have been relatively constant in recent years (see Figure 5, panel B, and Figure 7).

\section{Discussion}

Given their importance in collecting on and helping borrowers repay over $\$ 1$ trillion in student loans, the economic incentives inherent in its government contracts can guide servicers' behavior and influence their success in achieving goals of the government, borrowers, and the public. Servicers are compensated per borrower based largely on repayment status, which prioritizes default management above other goals such as borrower satisfaction. In recognizing the limitations in solely using a compensation per borrower schedule, the ED established a multifaceted set of goals for distributing new loans based on past performance, reflecting a multitournament format. Ranking servicers helps eliminate factors common to all servicers, such as a poor economy or changes to federal policy. Segmenting borrowers based on their characteristics for repayment 
metrics also helps further remove factors out of servicers' control such as whether the student graduated and age of the loan.

Public goals related to servicer practice, specifically repayment and borrower satisfaction, empirically conflict with each other, meaning increasing success in one may come at the expense of the other. For example, decreasing calls to borrowers may increase satisfaction but reduce repayment at the margin. This highlights how incentives in contracts, in this case, both what is included in relevant formulas and the weights assigned to them, can guide outcomes.

As servicers' actions to improve repayment appear to be negatively related to borrower satisfaction, we explored how complaints against servicers, a signal of dissatisfaction, relate to aspects of borrowing. It is possible that borrowers may target their dissatisfaction with student loan repayment experiences toward servicers because the servicer is with whom borrowers primarily interact no matter the issue. Over time, a larger share of complaints relates to account maintenance and information at the expense of other aspects like marketing, interactions, terms and fees, and payment handling.

As the ED moves toward its Next Gen servicing environment, many of the accountability structures and incentives inherent in existing contracts will change, but lessons from the current system can provide important insight. If different firms have control over only selected aspects of the servicing process - as opposed to one servicer largely overseeing the total experience under the current model - this will likely make it more difficult to pinpoint who should be held accountable for the overall repayment outcomes and the satisfaction of borrowers, postsecondary institutions, and aid professionals. This is likely to lead borrowers to focus their discontent largely at the ED and FSA and away from any single servicer. 


\section{References}

Abraham, K. G., E. Filiz-Ozbay, E. Y. Ozbay, and L. J. Turner. (2020). "Framing Effects, Earnings Expectations, and the Design of Student Loan Repayment Schemes." Journal of Public Economics 183, 104067.

ACS. (2004). "Amendment of Solicitation/Modification of Contract." Office of Federal Student Aid. https://www2.ed.gov/policy/gen/leg/foia/acscontract1.pdf.

Akers, B., and M. M. Chingos. (2014). Is a Student Loan Crisis on the Horizon? Brown Center on Education Policy at the Brookings Institution.

Avery, C., and S. Turner. (2012). "Student Loans: Do College Students Borrow Too Much - or Not Enough?” Journal of Economic Perspectives 26(1), 165-192.

Baum, S., M. Jennifer, P. Matea, and C. J. Libassi. (2018). Trends in Student Aid 2018. The College Board.

Bleemer, Z., and B. Zafar. (2018). "Intended College Attendance: Evidence from an Experiment on College Returns and Costs." Journal of Public Economics 157, 184-211.

Brooks, J. (2016, July). "Loan Servicing Information — Federal Loan Servicer Team Change." Federal Student Aid.

Campbell, C. (2019). The Long Path to a New Student Loan Repayment System. Washington, D.C.: Center for American Progress.

Campbell, C., and N. Hillman. (2015). A Closer Look at the Trillion: Borrowing, Repayment, and Default at Iowa's Community Colleges. The Association of Community College Trustees. Washington, D.C.

Card, D. (1999). “The Causal Effect of Education on Earnings.” In Handbook of Labor Economics (Vol. 3, pp. 1801-1863). Elsevier.

Congressional Research Service. (2019). "Federal and State Regulation of Student Loan Servicers: A Legal Overview." Congressional Research Service.

Consumer Finance Protection Bureau. (2017). “CFPB Sues Nation's Largest Student Loan Company Navient for Failing Borrowers at Every Stage of Repayment." Consumer Finance Protection Bureau.

Cowley, S. (2019, October). “New York Sues Student Loan Servicer for Abusive Acts.” New York Times. 
Cowley, S. (2020, February). “The Student Loan Appeal Process the Government Doesn't Tell you About.” New York Times.

Darolia, R. (2013). "Integrity versus Access? The Effect of Federal Financial Aid Availability on Postsecondary Enrollment." Journal of Public Economics 106, 101-114.

Darolia, R., and C. Harper. (2018). "Information Use and Attention Deferment in College Student Loan Decisions: Evidence from a Debt Letter Experiment." Educational Evaluation and Policy Analysis 40(1), 129-150.

Darolia, R., and D. Ritter. (2020). "Strategic Default Among Private Student Loan Debtors: Evidence from Bankruptcy Reform." Education Finance and Policy 1-52.

Delisle, J. D., and L. West. (2019). "Student Loan Servicers: Scammers or Scapegoats?" AEI Paper \& Studies.

DeVos, B. (2017, April 11). "Student Loan Servicer Recompete. Letter to James W. Runcie, Federal Student Aid." Washington, D.C.: U.S. Department of Education.

Dynarski, S. M., and J. E. Scott-Clayton. (2006). "The Cost of Complexity in Federal Student Aid: Lessons from Optimal Tax Theory and Behavioral Economics (w12227)." National Bureau of Economic Research.

Eidelman, S. (2020). "CFPB Study of Consumer Finances Following Early Pandemic Is Positive. Will Coming Months Paint a Different Story?" InsideARM.

Federal Student Aid. (2015). "Explanation of Allocation and Performance Measure Methodology." Federal Student Aid. https://studentaid.ed.gov/sa/about/datacenter/business-info/contracts/loan-servicing/servicerperformance\#Reports \%20by\%20Quarter.

Federal Student Aid. (2017). "Servicer Performance Metrics and Allocations." Federal Student Aid. https://studentaid.ed.gov/sa/about/data-center/business-info/contracts/loanservicing/servicer-performance\#Reports $\% 20$ by $\% 20$ Quarter.

Federal Student Aid. (2018). "Servicer Portfolio by Loan Status." Federal Student Aid. https://studentaid.ed.gov/sa/about/data-center/student/portfolio.

Fernandez, C. (2016). "Effective Counseling, Empowered Borrowers: An Evidence-based Policy Agenda for Informed Student Loan Borrowing and Repayment." Research Report. TG (Texas Guaranteed Student Loan Corporation).

Friedman, M. (1962). “Capitalism and Freedom.” University of Chicago.

Friedman, Z. (2019, January). "Navient Ranks Highest for Student Loan Complaints." Forbes. 
Gibbons, R., and J. Roberts. (2013). "Economic Theories of Incentives in Organizations." In Gibbons, R., and Roberts, J. (Eds.), Handbook of Organizational Economics (pp. 56-99). Princeton University Press.

Heinrich, C. J., and Y. Choi. (2007). "Performance-based Contracting in Social Welfare Programs." The American Review of Public Administration 37(4), 409-435.

Hernandes, J. (2013, July). "Loan Servicing Information - Additional Federal Loan Servicer Team Changes." Federal Student Aid. http://www.nasfaa.org/newsitem/1581/7 26 Loan Servicing Information Additional Federal Loan Servicer Team Changes.

Hernandes, J. (2014, November). "Loan Serving Information — Update on Loan Servicing Process Changes." Federal Student Aid.

Hillian, J. (2019, September). "Colorado Joins 31 States in Case Against Student Loan Servicer Navient." CBSN Denver.

Holmstrom, B. (1982). "Moral Hazard in Teams." The Bell Journal of Economics, 324-340.

Lee, D., W. Van der Klaauw, A. Haughwout, M. Brown, and J. Scally. (2014). "Measuring Student Debt and Its Performance." FRB New York Staff Report (668).

Lu, J. (2015). “The Performance of Performance-based Contracting in Human Services: A Quasi-Experiment." Journal of Public Administration Research and Theory 26(2), 277 293.

Mitchell, T. (2016, July 20). Policy Direction on Federal Student Loan Servicing. Letter to James Runcie, Federal Student Aid. Washington, D.C.: U.S. Department of Education.

Moretti, E. (2004). "Workers' Education, Spillovers, and Productivity: Evidence from PlantLevel Production Functions. American Economic Review 94(3), 656-690.

Navient. (2014). "Amendment of Solicitation/Modification of Contract." Federal Student Aid. https://studentaid.ed.gov/sa/about/data-center/business-info/contracts/loan-servicing.

New York Attorney General. (2019). "AG James Sues Student Loan Servicer for Mismanaging Loan Forgiveness Program.” New York State Office of the Attorney General.

Office of Inspector General. (2019). "Federal Student Aid: Additional Actions Needed to Mitigate the Risk of Servicer Noncompliance with Requirements for Servicing Federally Held Student Loans." Department of Education. 
O’Flaherty, S., and C. Battle. (2013). "Loan Servicing Update." 2013 NASFAA, U.S. Department of Education.

Oreopoulos, P., and K. G. Salvanes. (2011). "Priceless: The Nonpecuniary Benefits of Schooling." Journal of Economic Perspectives 25(1), 159-184.

Ortiz, E. (2019). "Student Debt Scams Flourish with Rise in Robocalls, Advocates Say." NBC News (24 June 2019). https://www.nbcnews.com/news/education/student-debt-scamsflourish-rise-robocalls-advocates-say-n1016921.

Rosato, D. (2017, April). “Complaints About Student Loan Servicers Mount.” Consumer Reports.

Rubenstein, R., A. E. Schwartz, and L. Stiefel. (2003). "Better Than Raw: A Guide to Measuring Organizational Performance with Adjusted Performance Measures." Public Administration Review 63(5), 607-615.

U.S. Department of Education. (2009). "Phase I A. E. - Solicitation. Title IV Loan Servicing/Management Program (Title IV)." Office of Federal Student Aid.

U.S. Department of Education. (2010). "Solicitation/Contract/Order for Commercial Items." Office of Federal Student Aid.

U.S. Department of Education. (2019, May). "Secretary DeVos Announces Intent to Enhance FSA's Next Generation Processing and Servicing Environment." U.S. Department of Education Press Office. https://www.ed.gov/news/press-releases/secretary-devosannounces-intent-enhance-fsas-next-generation-processing-and-servicing-environment.

U.S. Department of Education. (2020, June). "U.S. Department of Education's Office of Federal Student Aid Announces New Contracts with Five Companies to Improve Customer Service, Increase Accountability." Department of Education Press Office. https://www.ed.gov/news/press-releases/us-department-educations-office-federal-studentaid-announces-new-contracts-five-companies-improve-customer-service-increaseaccountability. 


\section{Figure 1: Student Loan Servicers over Time}

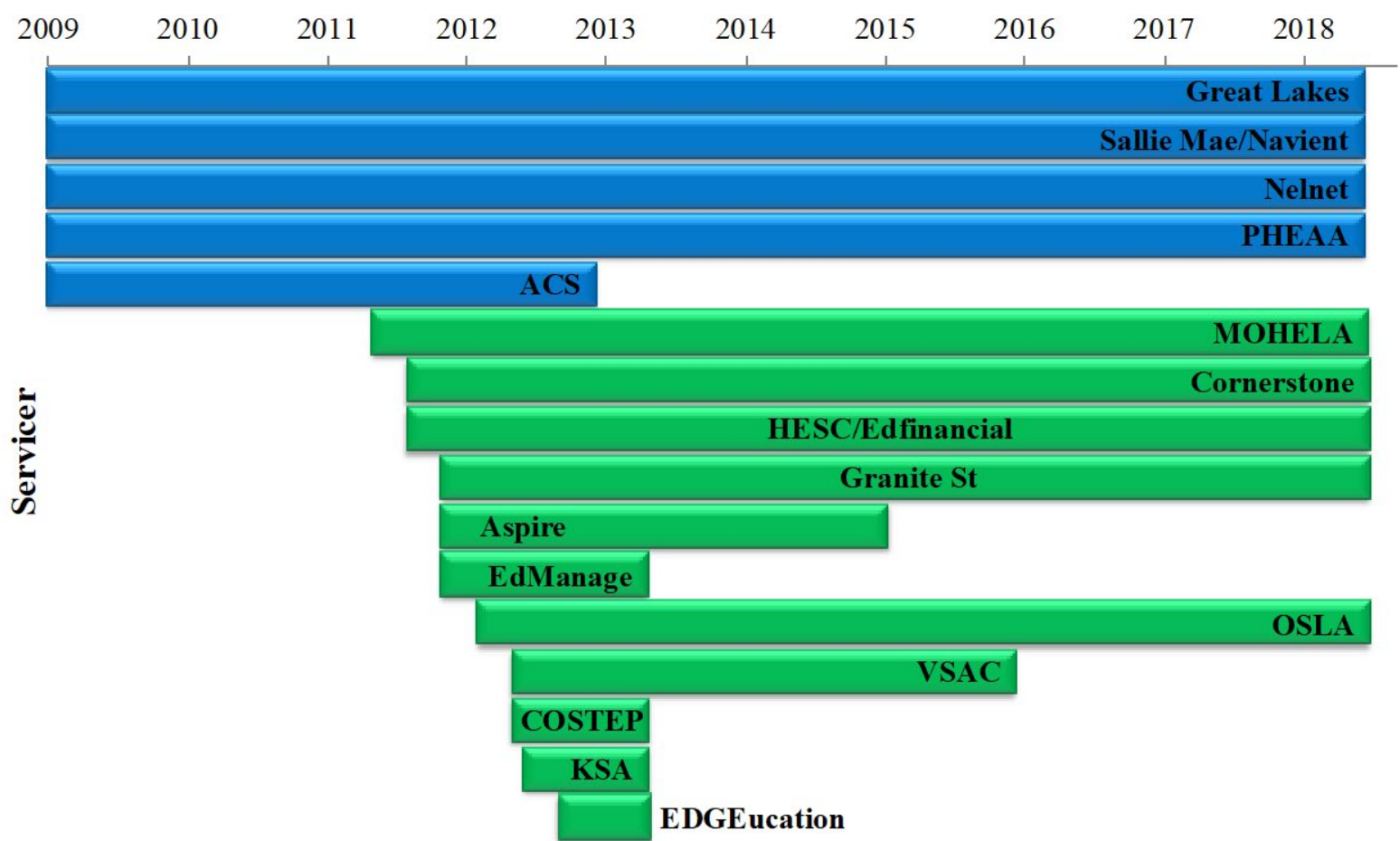

Notes: Timeline shows contracts for servicing federal student loans as of 2009. Dates are based on contracts published in the FSA data center and announcements. Great Lakes and Nelnet announced a merger in 2018 to become GreatNet; however, we consider them separately here since FSA measured performance and new loan allocations for these two firms separately as of the end of our analysis period (June 2018). 
Figure 2: Loan Dollars Outstanding by Servicer

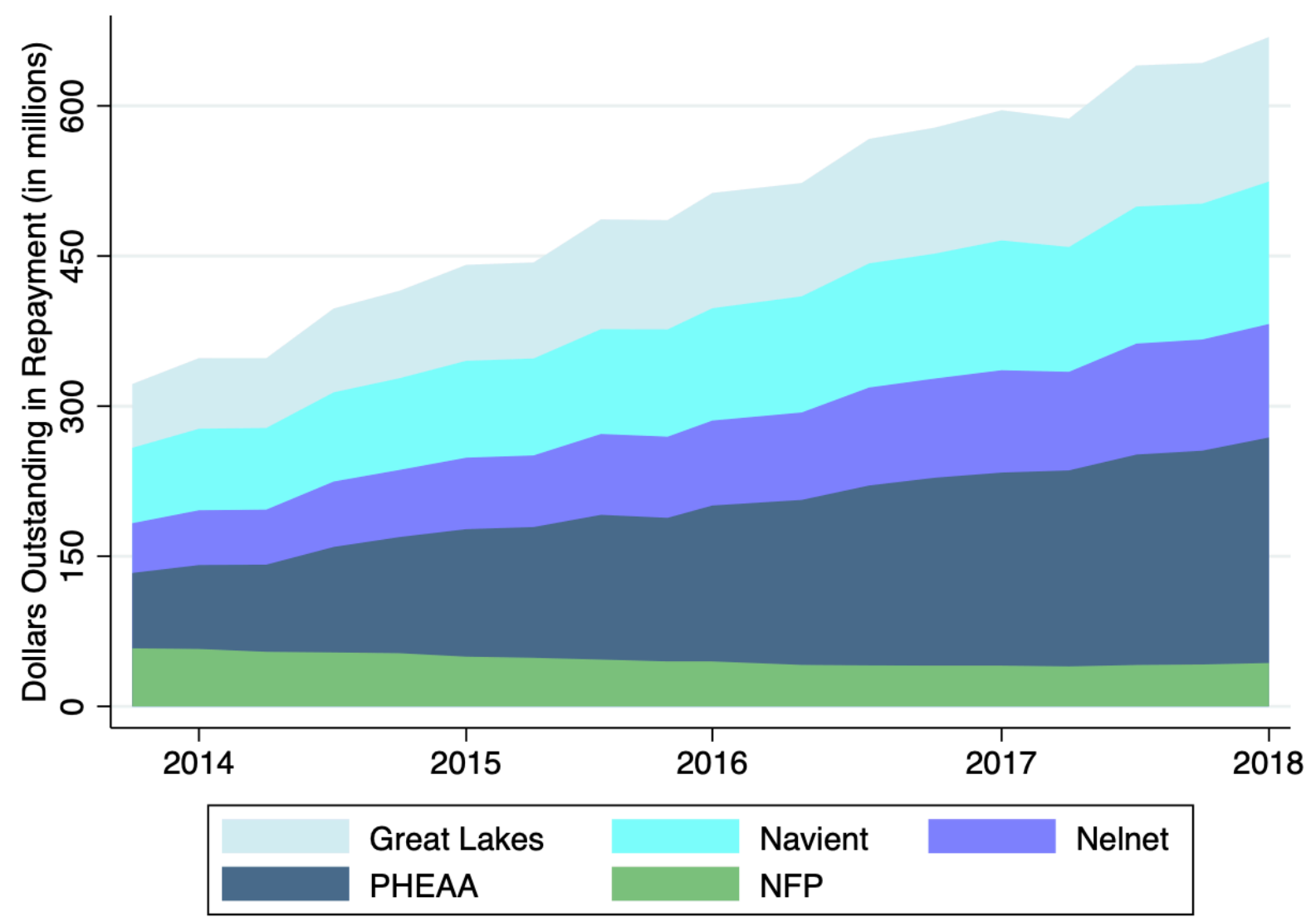

Notes: Data come from Federal Student Aid quarterly reports on servicer portfolio by loan status (Federal Student Aid, 2018a). Loans in repayment are actively in repayment status and fewer than 361 days delinquent. Dollars outstanding include both principal and interest accumulated. 
Figure 3: Servicer Compensation per Borrower

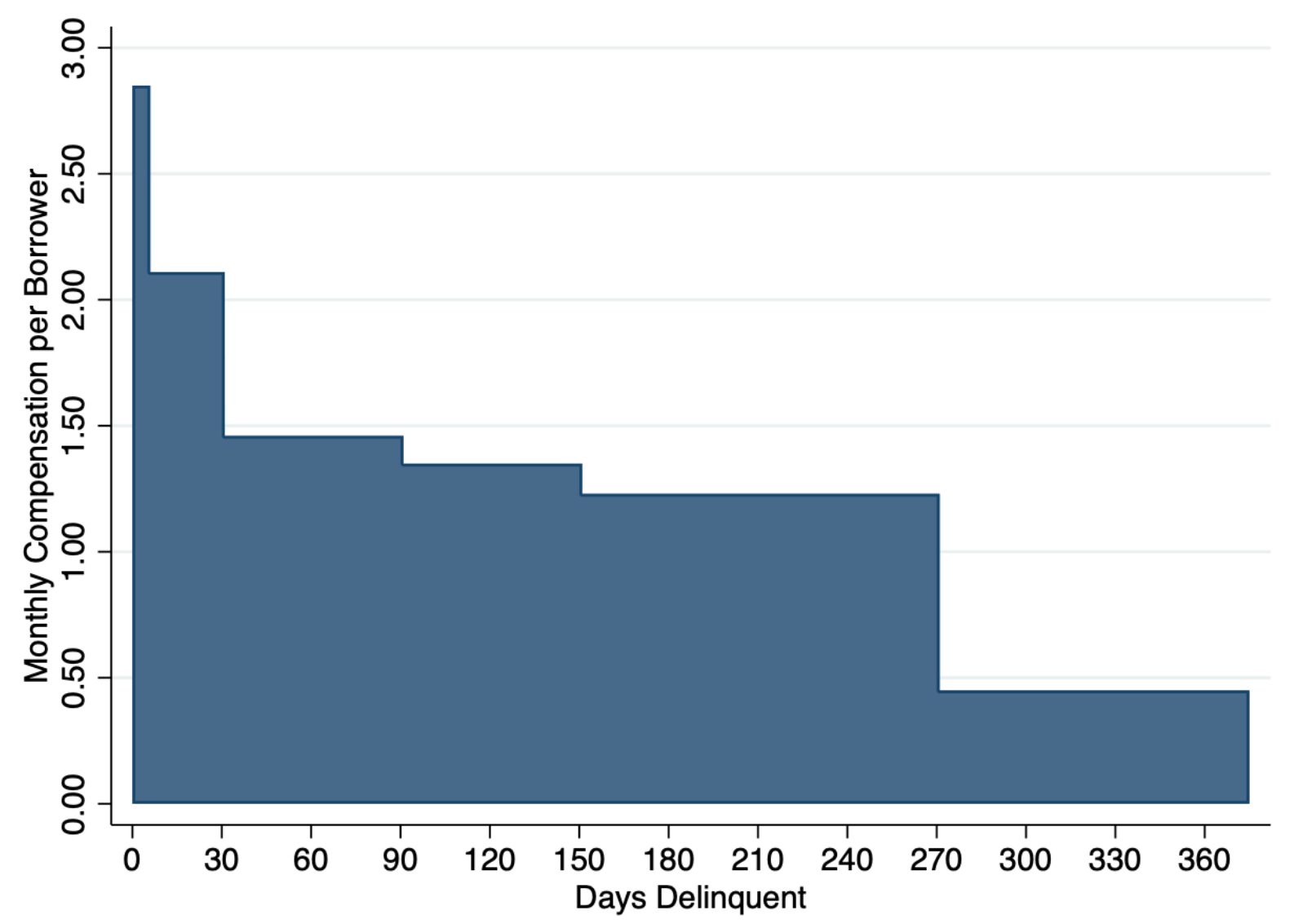

Notes: Figure shows monthly compensation in dollars per borrower for servicers based on most recent rates published in the TIVAS 2014 contract (Navient, 2014). 
Figure 4: Proportion of New Borrower Allocations by Servicer

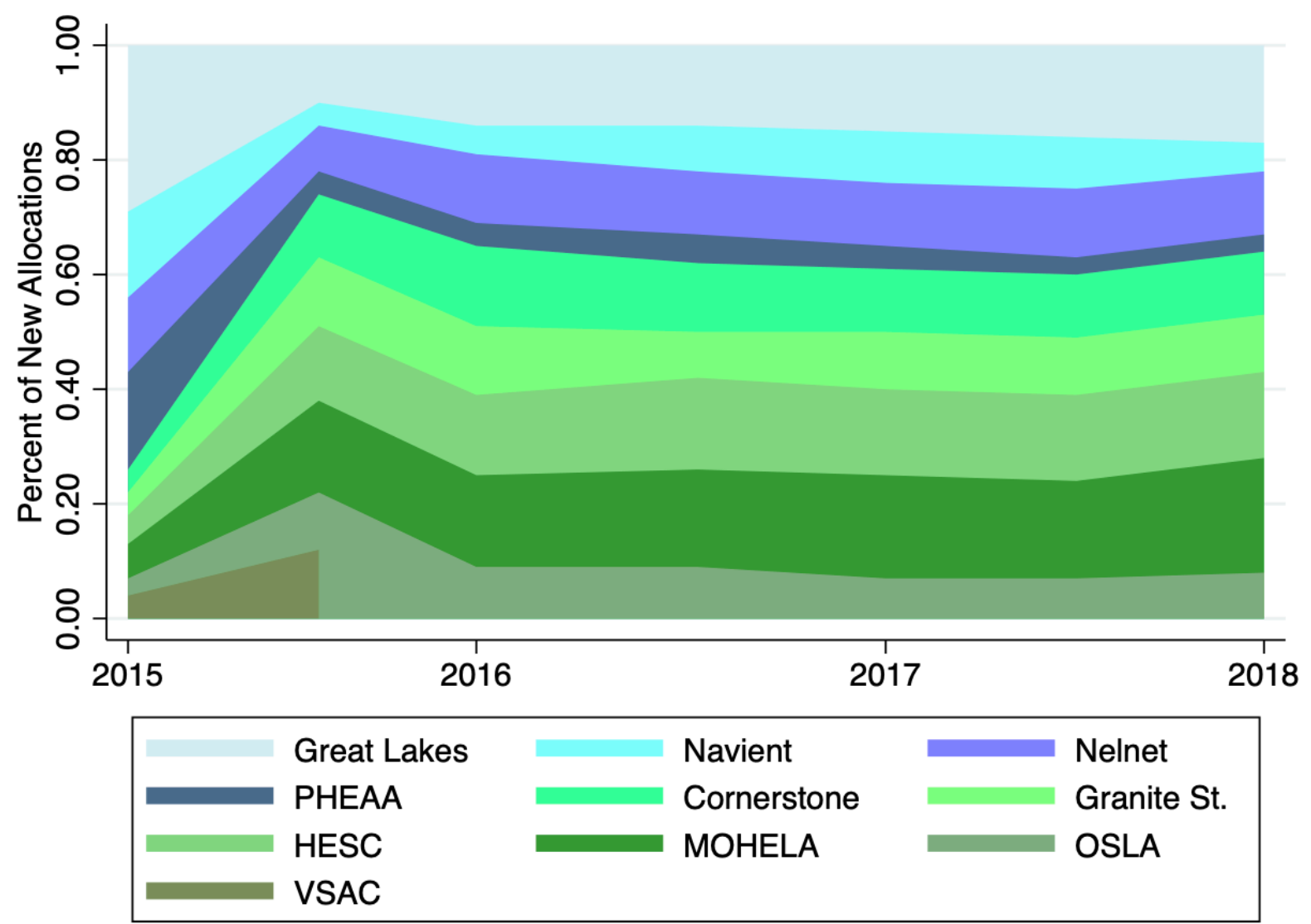

Notes: New allocation amounts by servicer are the number of borrowers allocated to each servicer semiannually from FSA allocation reports. Data begin in the 4th quarter 2014 and are from Federal Student Aid quarterly servicer performance and allocations reports (Federal Student Aid, 2017). TIVAS servicers are shades of blue and NFP servicers shades of green. 


\section{Figure 5: Trends in Servicer Performance, Repayment Rates}

(A) Repayment Rates, National

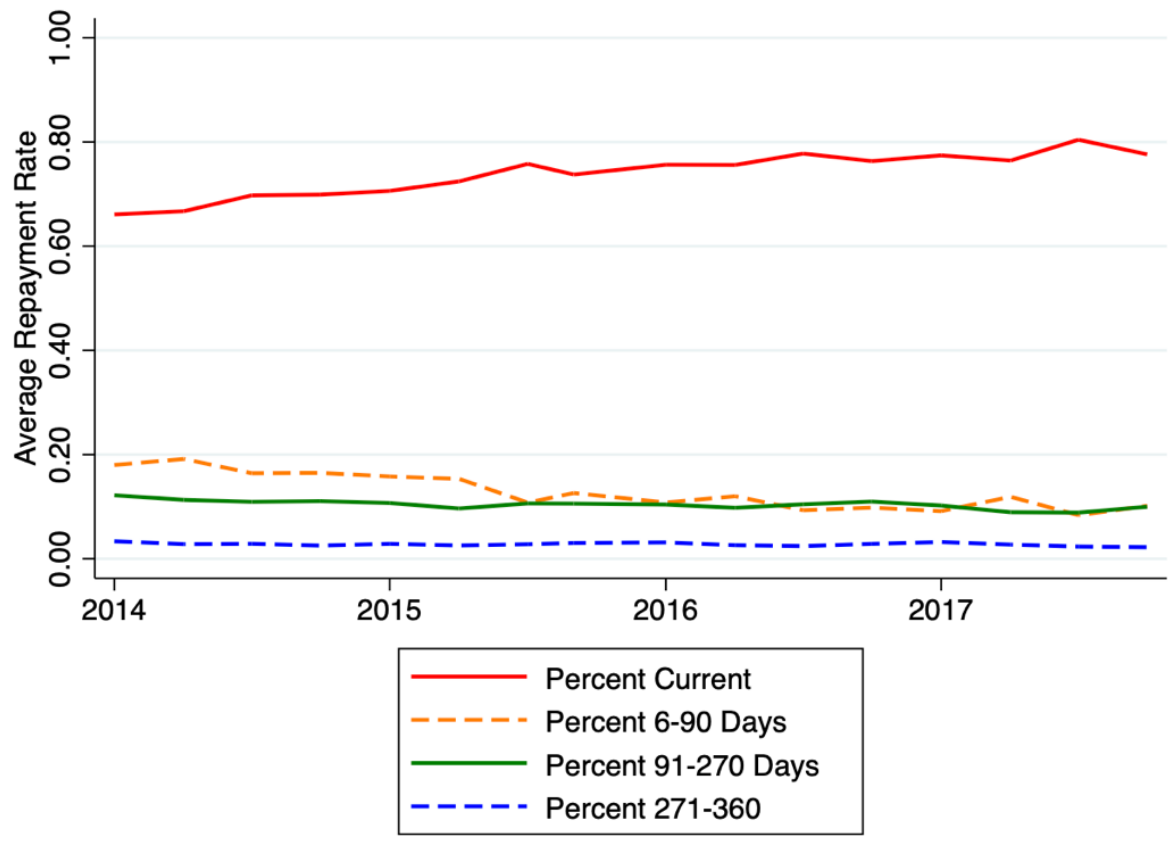

(B) Surveys, National

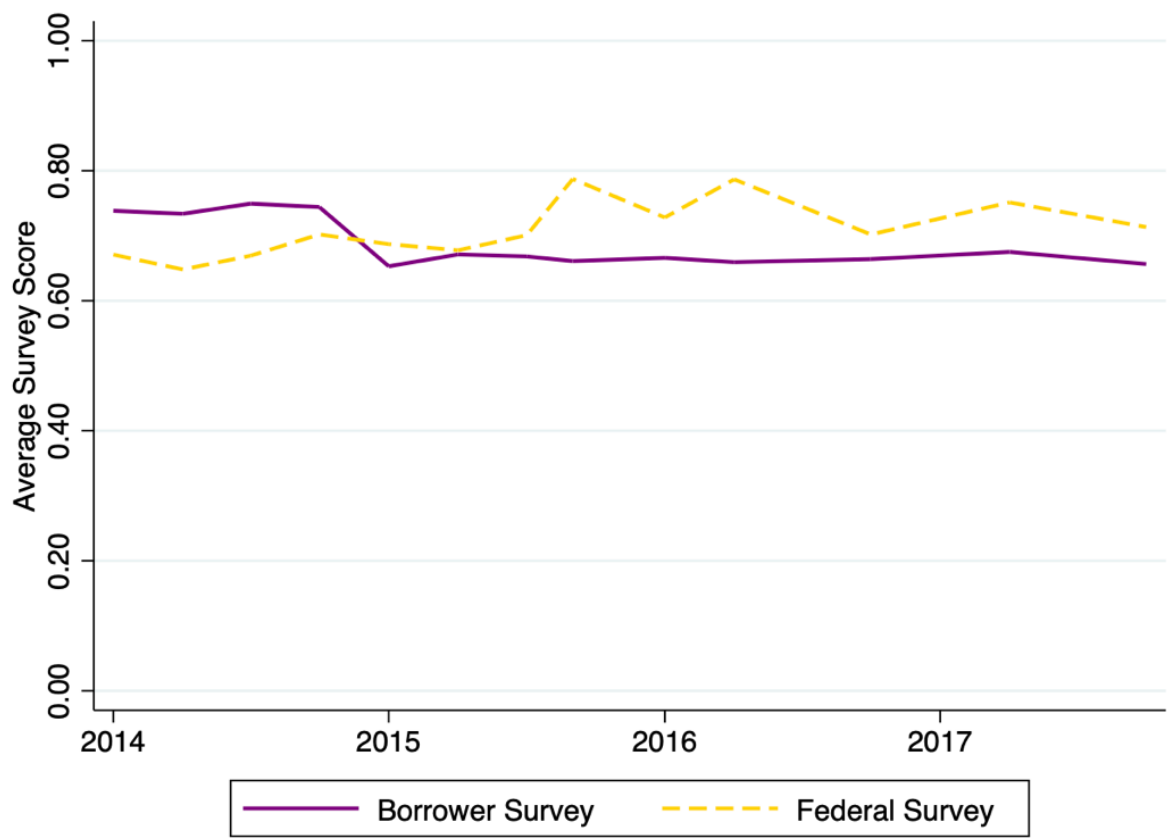

Notes: Data come from Federal Student Aid quarterly servicer performance and allocations reports (Federal Student Aid, 2017). Observations are by quarter and weighted by servicer by federal loans serviced as of 2018 shown in Table 1. Data begin in 2nd quarter 2014. 


\section{Figure 6: Trends in Current Repayment by Servicer}

(A) TIVAS

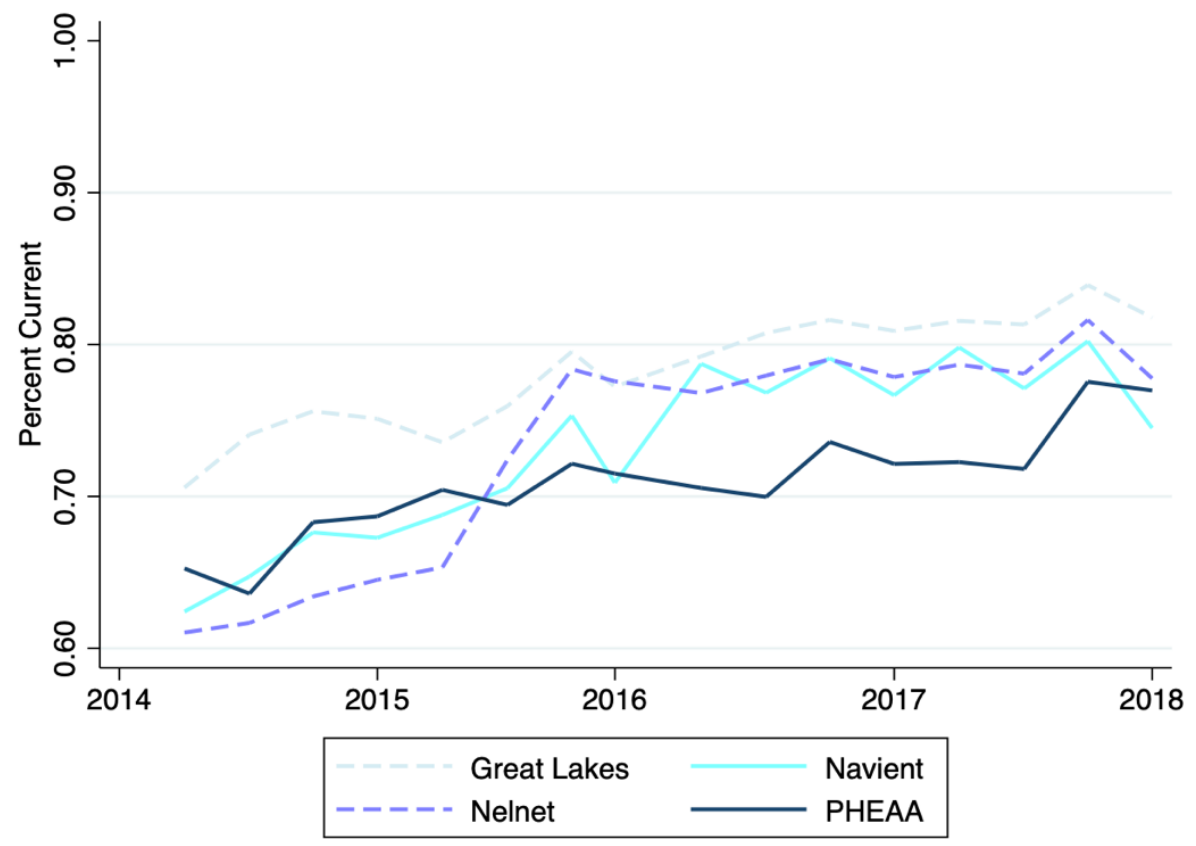

(B) NFPs

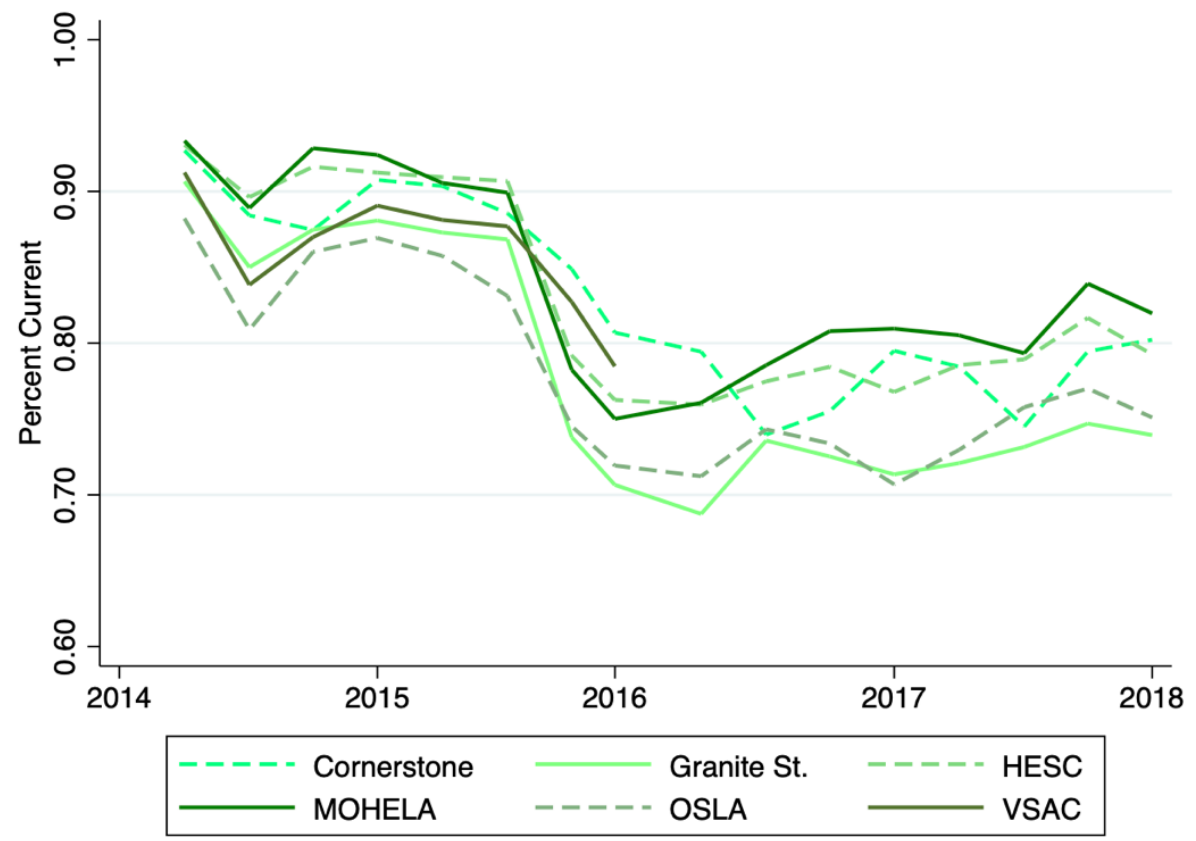

Notes: Data come from Federal Student Aid quarterly servicer performance and allocations reports (Federal Student Aid, 2017) and begin in 3rd quarter 2014. Graphs show trends in percent of borrowers in repayment that are fewer than six days delinquent by servicer. 
Figure 7: Trends in Borrower Survey by Servicer

(A) TIVAS

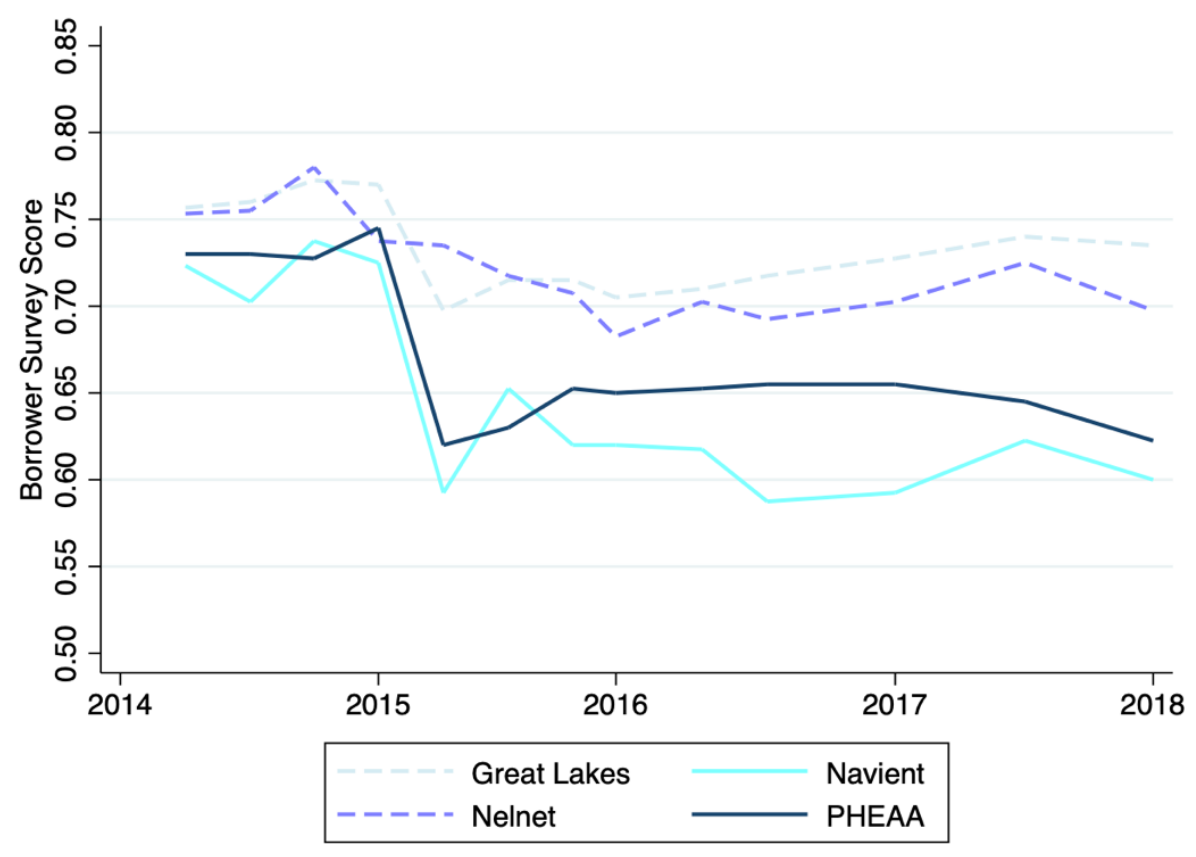

(B) NFPs

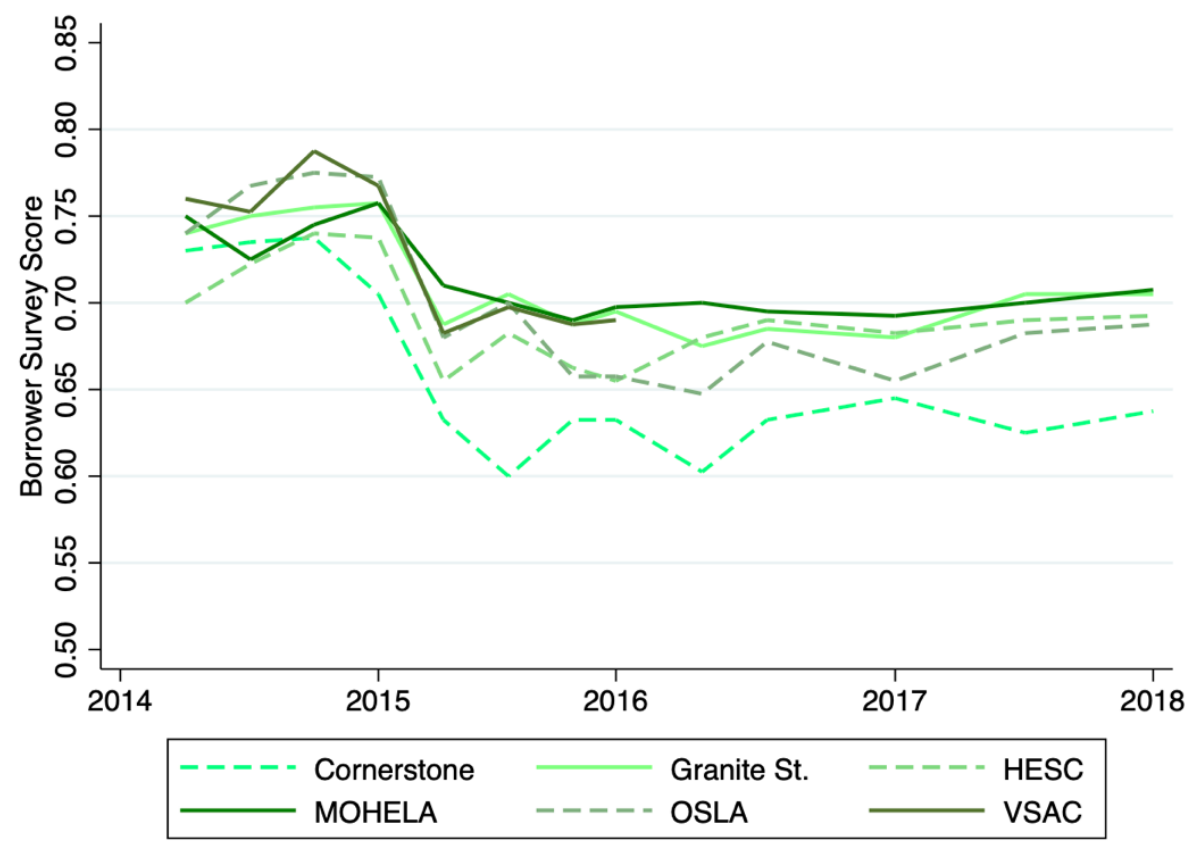


Notes: Data come from Federal Student Aid quarterly servicer performance and allocations reports (Federal Student Aid, 2017) and begin in 3rd quarter 2014. Graphs show trends in borrower survey score by servicer.

\section{Figure 8: Weighting Simulations}

\section{(A) Current Allocation and Equal Weight Simulation}

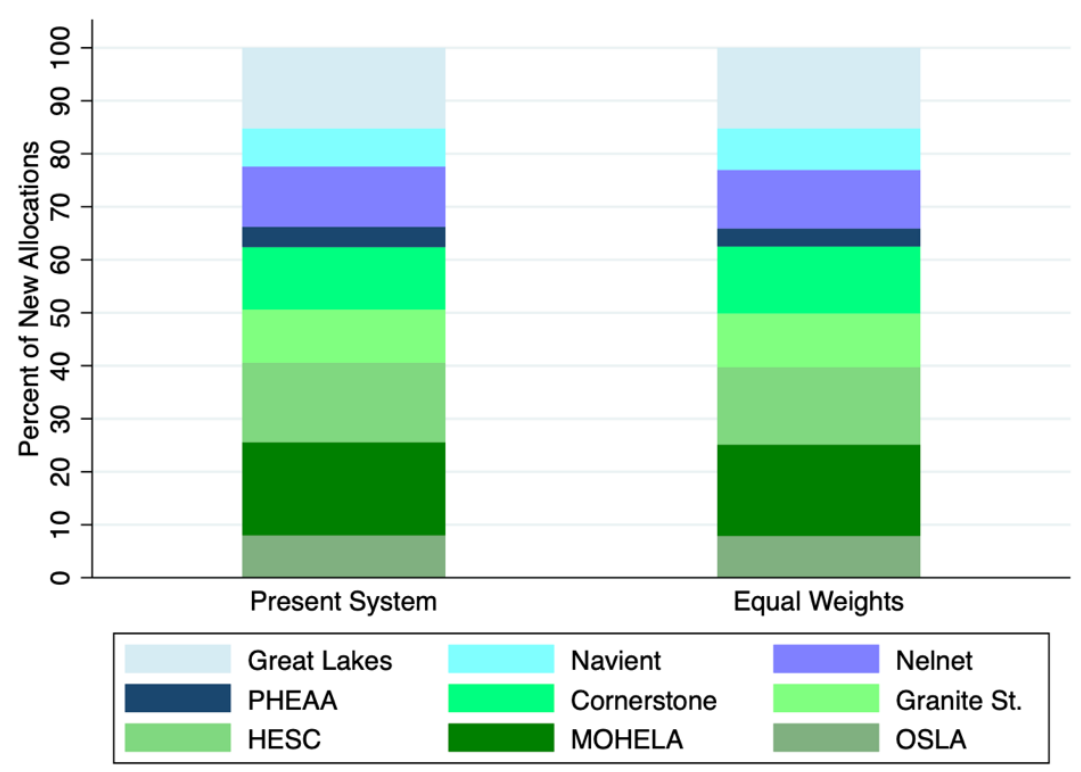

(B) Sole Weight Simulation

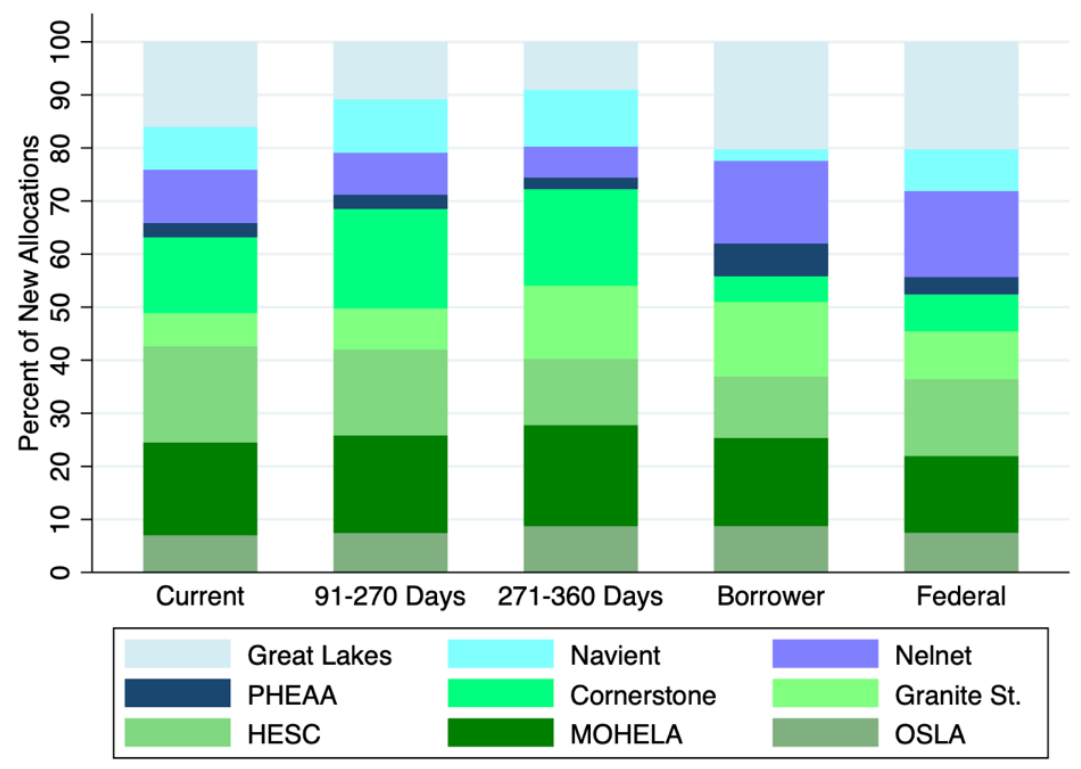

Notes: Data come from Federal Student Aid quarterly servicer performance and allocations reports (Federal Student Aid, 2017), split by servicer, beginning in 1st quarter 2016 through Q2 2018. Allocations are simulated based on changing metric weights while using true performances by metric. In panel A, "Equal weights" gives each metric a 
$20 \%$ weight. In panel $\mathrm{B}$, each bar shows the average new allocation by servicer if the metric weight were $100 \%$. Servicer allocations within each bar are the average allocation for the servicer over the time period. 


\section{Figure 9: Relationship Between Current Repayment/Borrower and Federal Surveys}

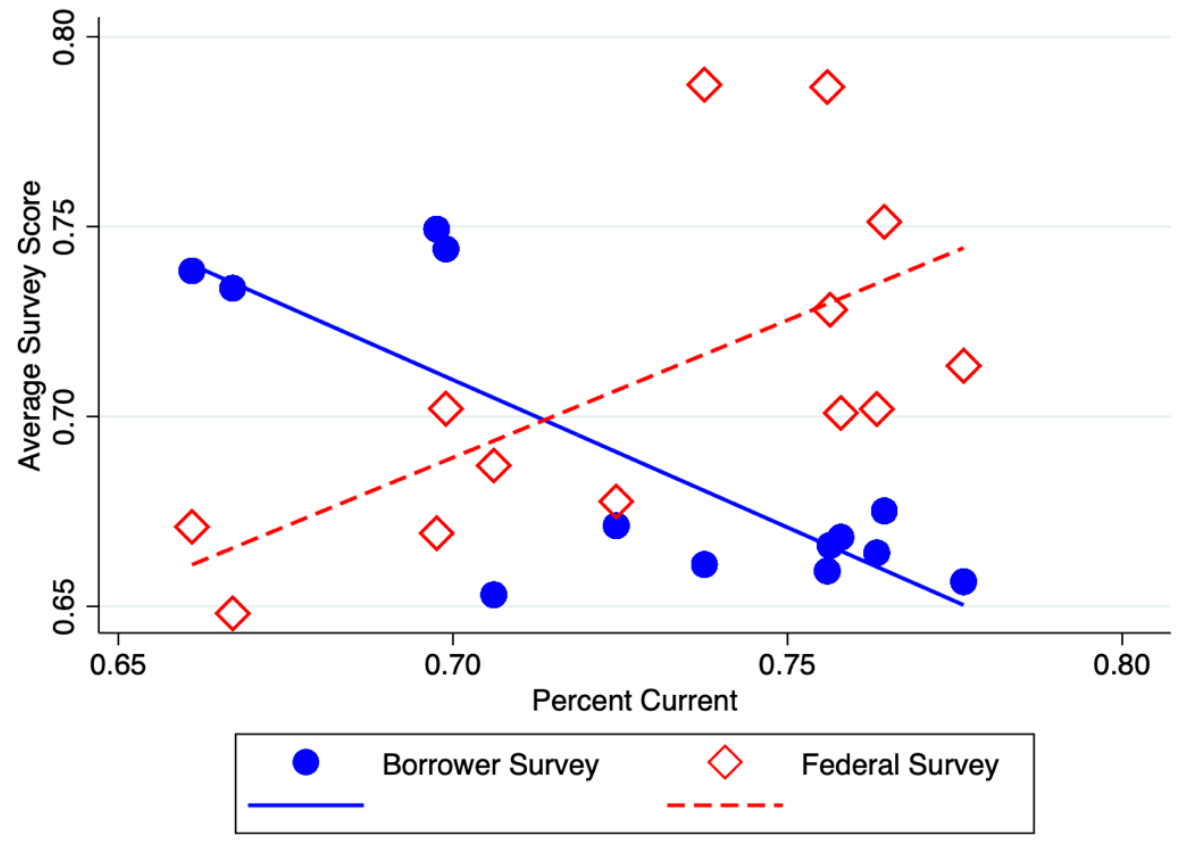

Notes: Data come from Federal Student Aid quarterly servicer performance and allocations reports (Federal Student Aid, 2017). Observations are by quarter beginning in 3rd quarter 2014 and weighted by servicer by federal loans serviced as of 2018 shown in Table 1. The graph shows correlations between percent of borrowers in repayment that are fewer than six days delinquent and borrower survey and federal personnel survey scores. 


\section{Figure 10: Trends in Servicer Complaints}

(A) Overall

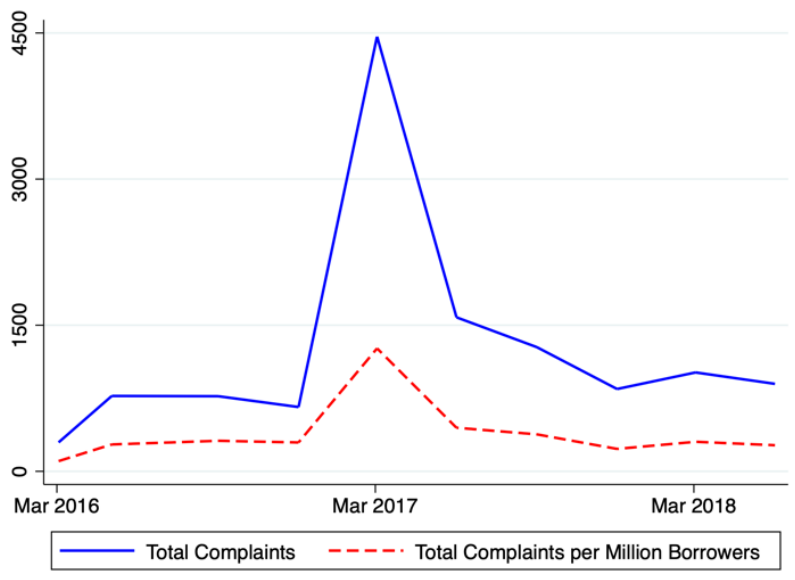

(B) Navient Separate from Other Servicers

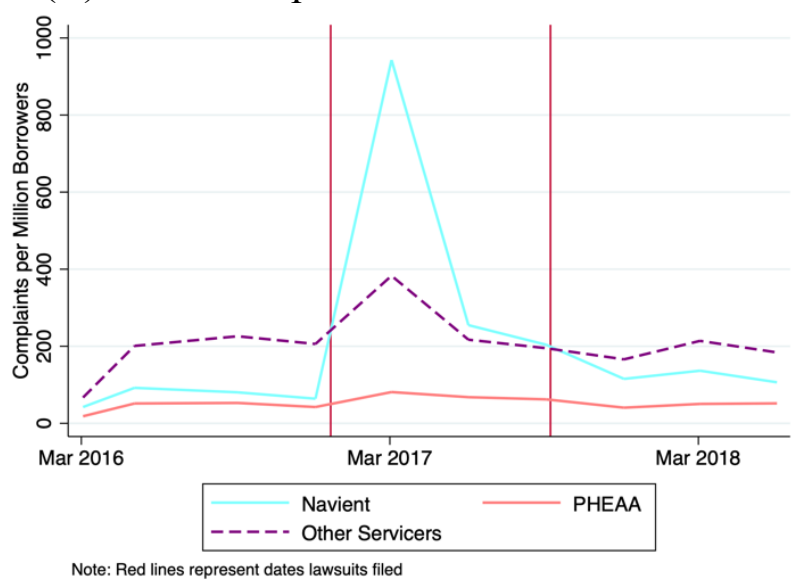

Notes: Data come from the Consumer Finance Protection Bureau complaint database, starting from March 2016 through June 2018. Vertical red lines are lawsuits filed by state attorney generals against Navient in January and October 2017, respectively. Complaints only include those with a subproduct of federal student loan. 


\section{Figure 11: Trends in Complaint Category Shares}

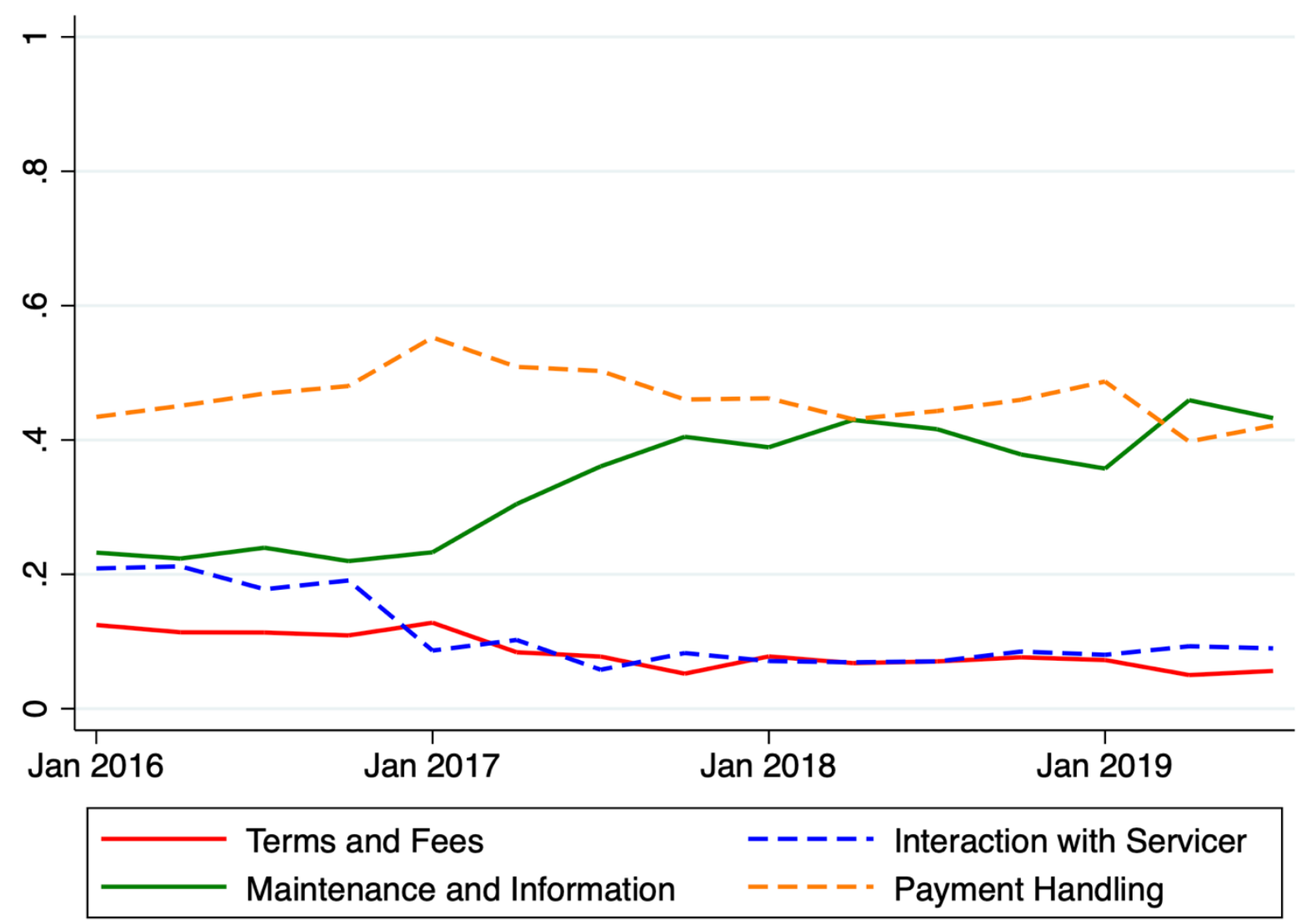

Notes: Data come from the Consumer Finance Protection Bureau complaint database, starting from January 2016 through July 2019. Figure shows trends by quarter of percent of complaints for all servicers by terms and fees, handling payments, interactions with servicers and marketing, or account maintenance and information. Complaints only include those with a subproduct of federal student loan. 
Table 1: Servicers' Student Loan Portfolios 2018/2019

\begin{tabular}{|l|c|c|c|c|}
\hline & \multicolumn{2}{|c|}{ Federal Student Loans Serviced } & \multicolumn{2}{c|}{$\begin{array}{c}\text { Non-Federal Student Loans } \\
\text { Serviced }\end{array}$} \\
\hline & $\#$ (millions) & \$ (billions) & \# (millions) & (billions) \\
\hline TIVAS & & & & 56.7 \\
\hline PHEAA $^{+}$ & -- & 394.8 & -- & 22.1 \\
\hline Navient & 5.90 & 293.0 & -- & N/A \\
\hline Great Lakes & 7.40 & 237.1 & N/A & 16.1 \\
\hline Nelnet & 7.36 & 219.0 & 0.7 & \\
\hline & & & & 15.7 \\
\hline NFPs & & & & N/A \\
\hline MOHELA $^{+*}$ & 2.00 & 37.6 & -- & -- \\
\hline HESC $^{+*}$ & 0.90 & 8.6 & N/A & N/A \\
\hline OSLA $^{+*}$ & 0.55 & 7.1 & -- & N/A \\
\hline Cornerstone & 0.31 & 1.5 & N/A & N/A \\
\hline Granite State & 0.02 & 0.2 & & \\
\hline
\end{tabular}

Notes: Data are from March 2019 quarterly or 2018 annual reports and show average amounts over the quarter or year. N/A indicates the given NFP did not servicer non-Federal student loans. " "__" indicates data could not be found for the field within the quarterly or annual reports. 
Table 2: Allocation Measures, 2016-present

\begin{tabular}{|c|c|c|c|}
\hline Category & Category Weight & Metric & Metric Weight \\
\hline \multirow{3}{*}{ Repayment Status } & \multirow{3}{*}{$60 \%$} & $\%$ Current & $30 \%$ \\
\hline & & $\begin{array}{l}\text { \% 91-270 Days } \\
\text { Delinquent }\end{array}$ & $15 \%$ \\
\hline & & $\begin{array}{c}\text { \% 271-360 Days } \\
\text { Delinquent }\end{array}$ & $15 \%$ \\
\hline Borrower Satisfaction & $35 \%$ & $\mathrm{n} / \mathrm{a}$ & $\mathrm{n} / \mathrm{a}$ \\
\hline $\begin{array}{c}\text { Federal Personnel } \\
\text { Satisfaction }\end{array}$ & $5 \%$ & $\mathrm{n} / \mathrm{a}$ & $\mathrm{n} / \mathrm{a}$ \\
\hline
\end{tabular}

Notes: Metrics and weights come from Federal Student Aid's "Explanation of Allocation and Performance Measure Methodology" (Federal Student Aid, 2015). 
Table 3: Estimates of Repayment Metrics

\begin{tabular}{|lccc|}
\hline Panel A. Percent Current & $(1)$ & $(2)$ & $(3)$ \\
\hline Borrower Survey & $-0.67^{* * *}$ & & $-0.61^{* * *}$ \\
& $(0.10)$ & & $(0.06)$ \\
Federal Survey & & 0.30 & 0.16 \\
& & $(0.17)$ & $(0.09)$ \\
Observations & 117 & 117 & 117 \\
\hline Panel B. Percent Severely Delinquent & $(1)$ & $(2)$ & $(3)$ \\
& -0.00 & & 0.00 \\
Borrower Survey & $(0.02)$ & & $(0.01)$ \\
& & 0.01 & 0.01 \\
Federal Survey & & $(0.02)$ & $(0.01)$ \\
& & 112 & 112 \\
Observations & 112 & Yes & Yes \\
\hline $\begin{array}{l}\text { Servicer Fixed Effects } \\
\text { Quarter-Year Fixed Effects }\end{array}$ & Yes & Yes & \\
\hline
\end{tabular}

Notes: Data come from Federal Student Aid quarterly servicer performance and allocations reports (Federal Student Aid, 2017). Data are for 3rd quarter 2014 through 2nd Q 2018. Unit of observation is servicer-by-quarter. Percent Current is percent of borrowers fewer than six days delinquent. Percent Severely Delinquent is percent of borrowers 271-360 days delinquent. Borrower and federal surveys are on a scale of 0 to 1 . Robust standard errors are shown in parentheses. All metrics are weighted by the servicer's share of total loan dollars outstanding. Servicer and quarteryear fixed effects included in all models. Panel B has five fewer observations as the NFPs did not have a severely delinquent reported for the first quarter.

$* * * \mathrm{p}<0.001,{ }^{* *} \mathrm{p}<0.01,{ }^{*} \mathrm{p}<0.05$ 


\section{Appendix Figure A1: Borrowers in Repayment by Servicer}

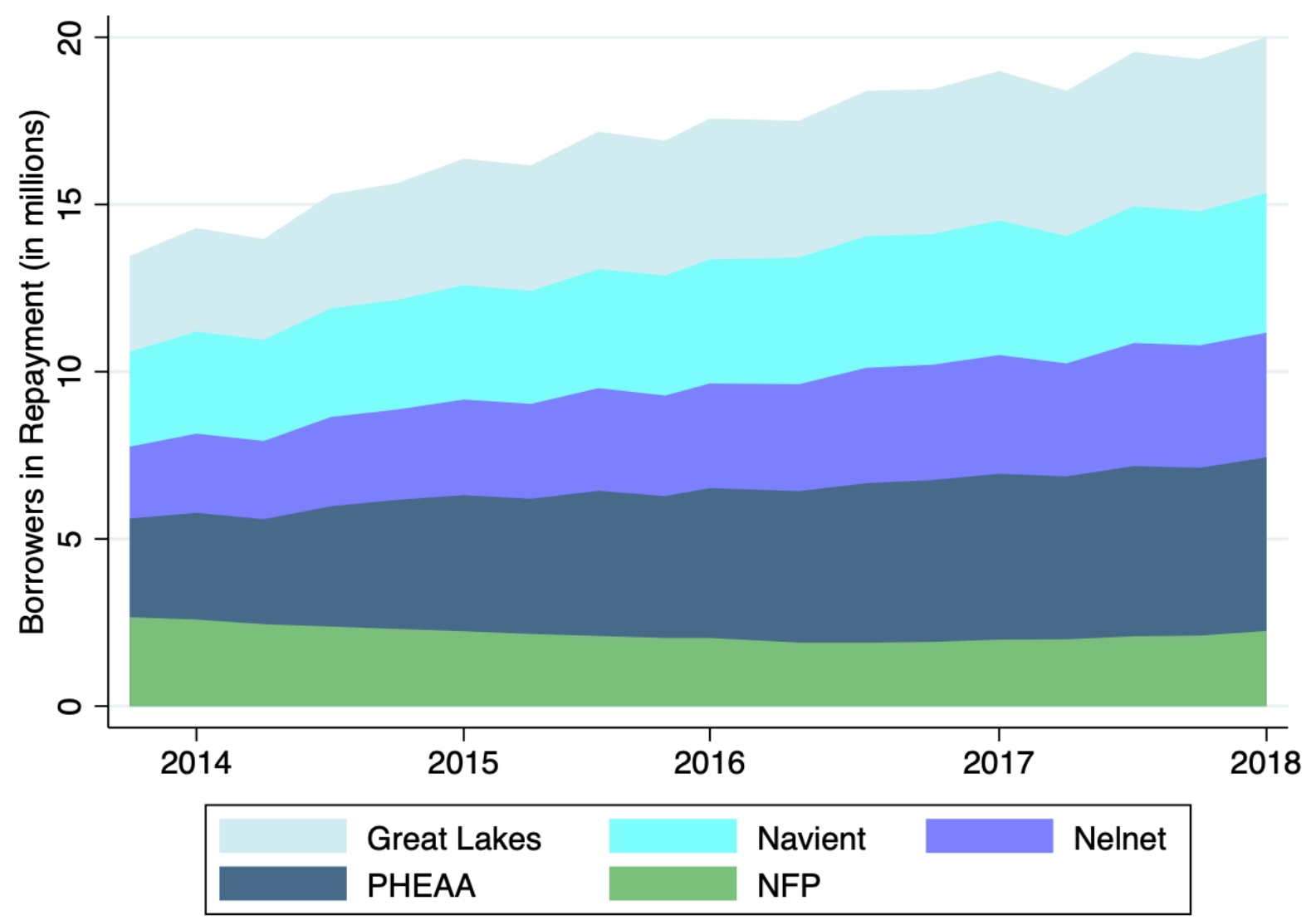

Notes: Data come from Federal Student Aid quarterly reports on servicer portfolio by loan status (Federal Student Aid, 2018a). Borrowers in repayment are current or fewer than 361 days delinquent. 


\section{Appendix Figure A2: Trends in Repayment Status, by Segment}

(A) Current Repayment

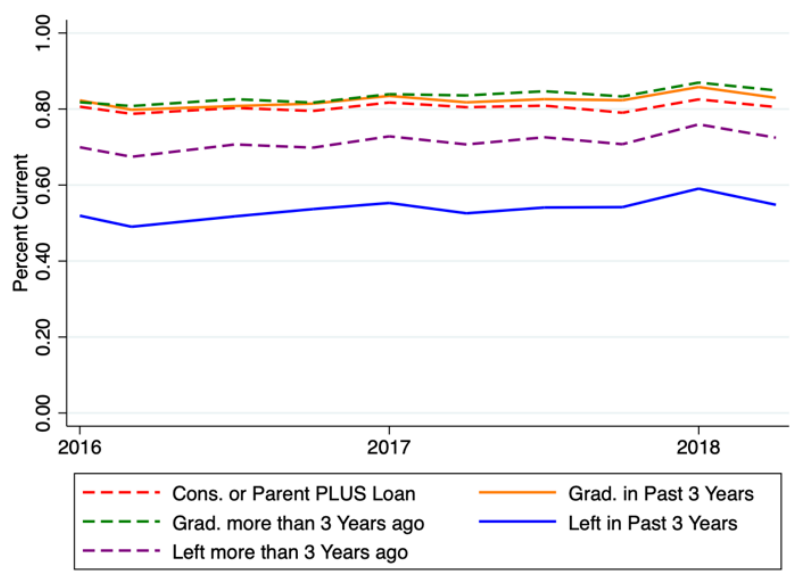

(B) \% Moderately Delinquent

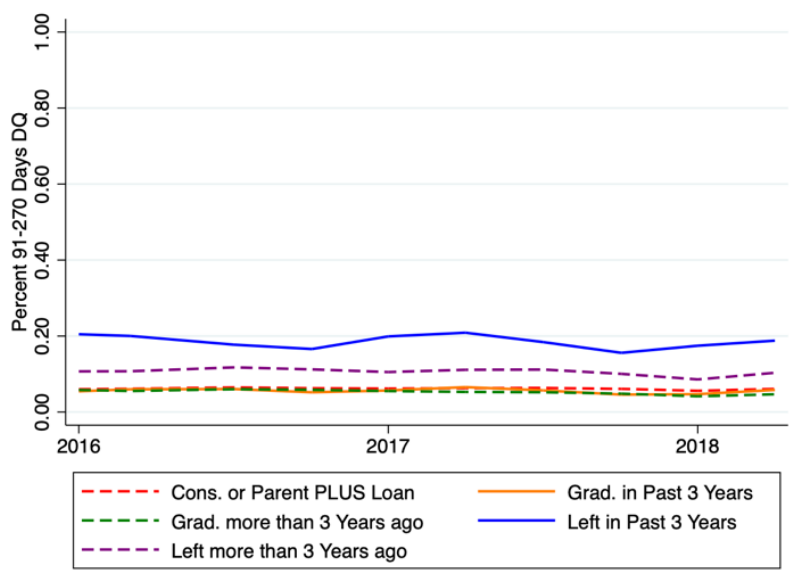

(C) \% Severely Delinquent

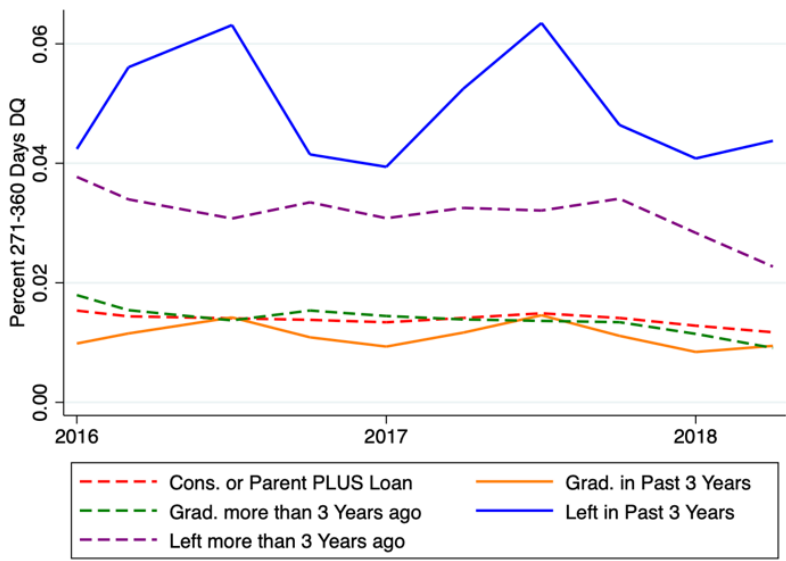

Notes: Data come from Federal Student Aid quarterly servicer performance and allocations reports (Federal Student Aid, 2017) and are weighted by servicer by federal loans serviced as of 2018 shown in Table 1. Data begin in 1st quarter 2016, the first quarter metrics were subdivided by segment. 


\section{Appendix Figure A3: Trends in Delinquency by Servicer, 2014-2018}

(A) \% Moderately delinquent, TIVAS

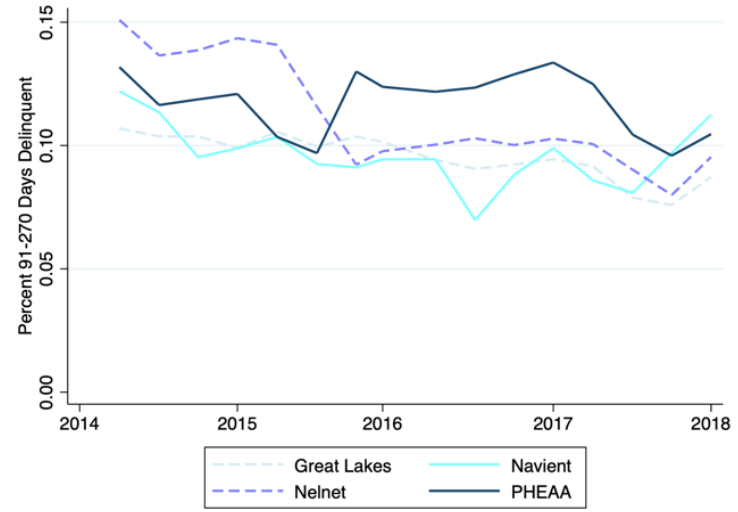

(B) $\%$ Severely delinquent, TIVAS

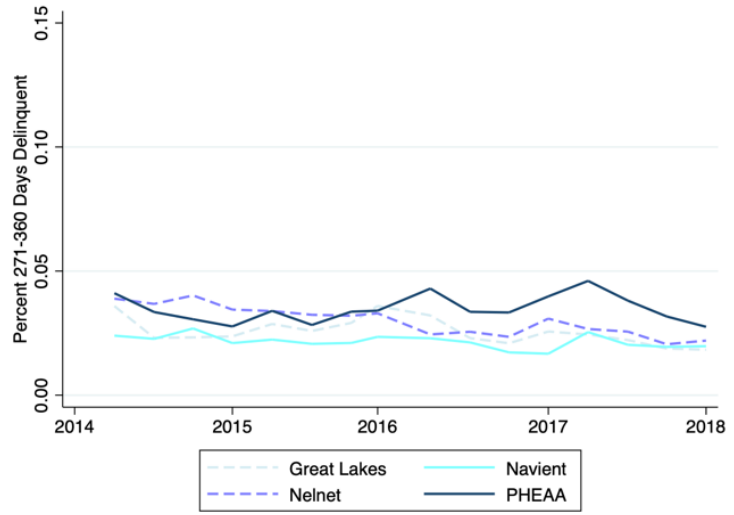

(C) \% Moderately delinquent, NFP

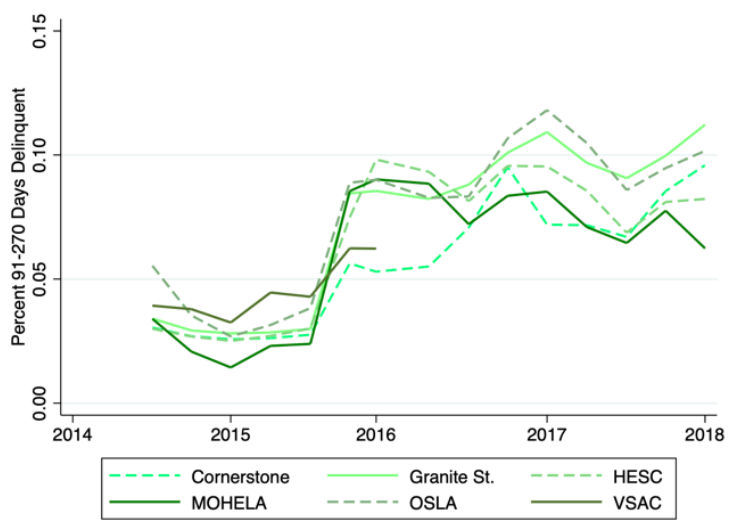

(D) $\%$ Severely delinquent, NFP

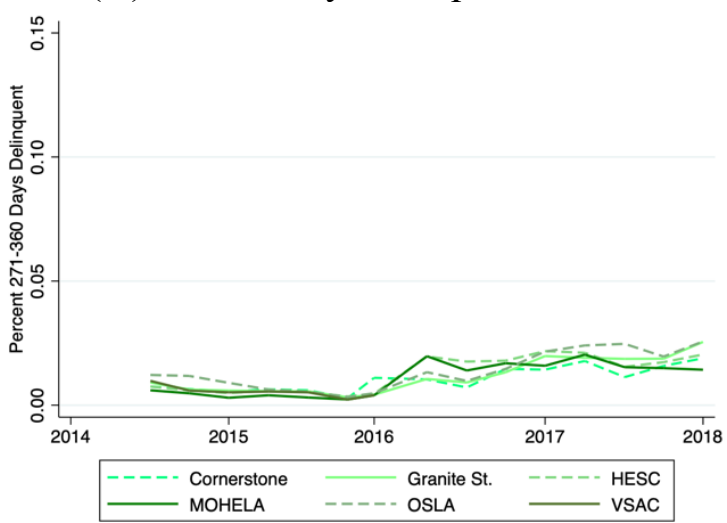

Notes: Data come from Federal Student Aid quarterly servicer performance and allocations reports (Federal Student Aid, 2017) and begin in 3rd quarter 2014. Graphs show trends in percent of borrowers in repayment who are moderately and severely delinquent. 


\section{Appendix Figure A4: Trends in Federal Survey by Servicer, 2014-2018}

(A) Federal Survey, TIVAS

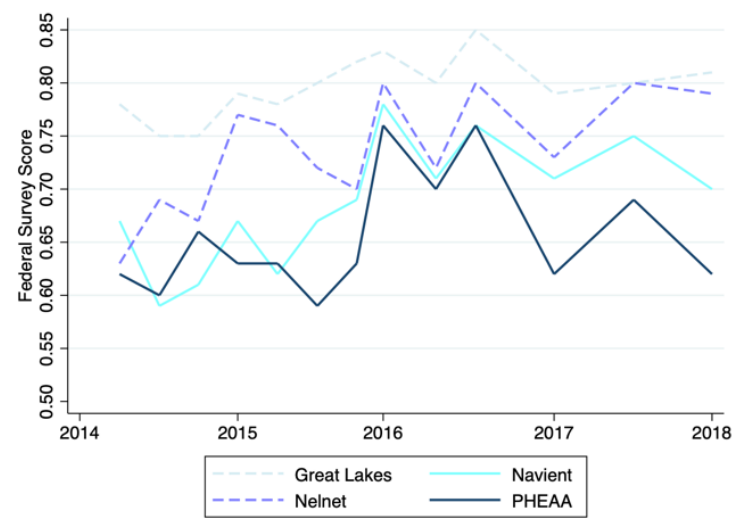

(B) Federal Survey, NFP

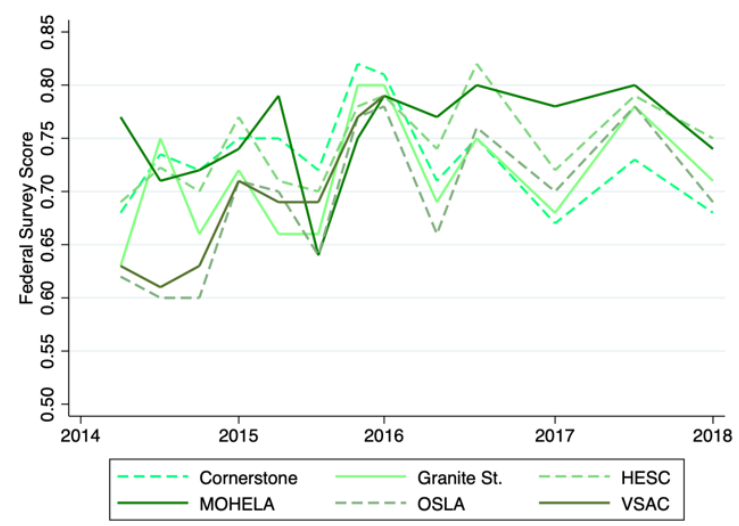

Notes: Data come from Federal Student Aid quarterly servicer performance and allocations reports (Federal Student Aid, 2017) and begin in 3rd quarter 2014. Graphs show trends in federal personnel survey score by servicer. 


\section{Appendix Figure A5: Relationship Between Delinquency and Surveys}

(A) Moderate Delinquency/Borrower and Federal Surveys

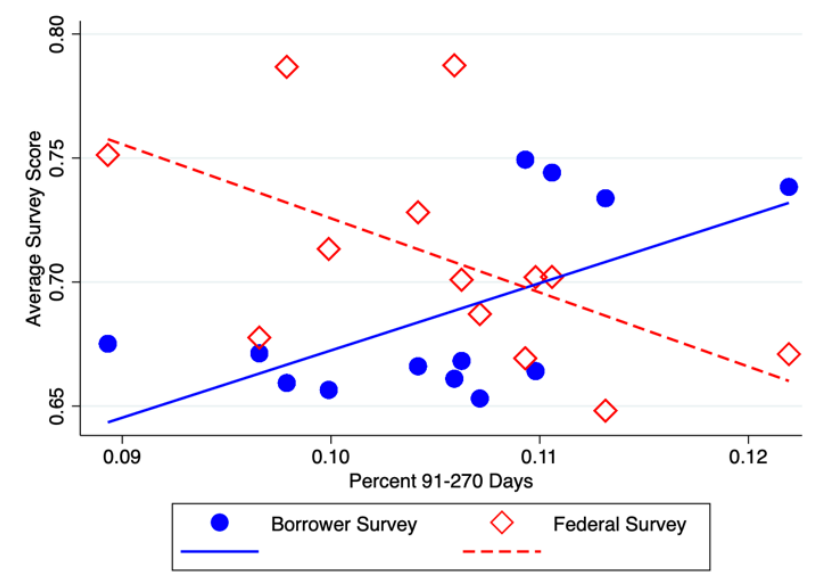

(B) Severe Delinquency/Borrower and Federal Surveys

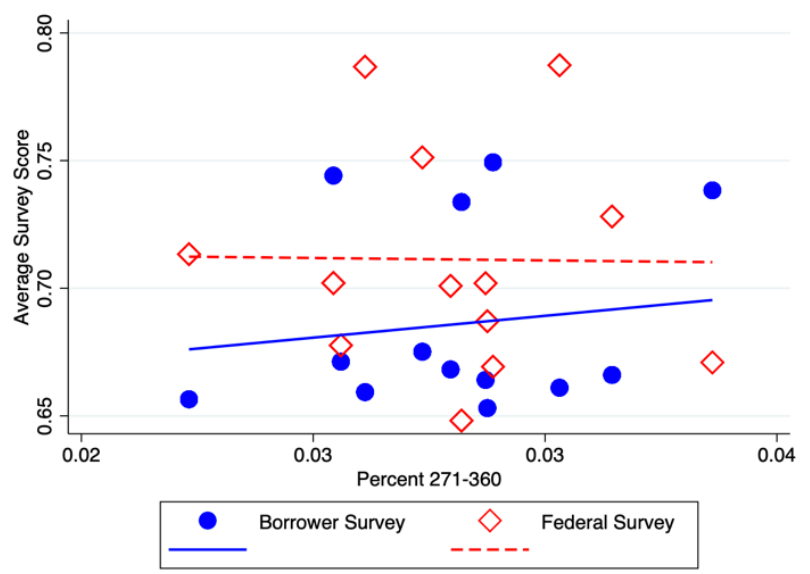

Notes: Data come from Federal Student Aid quarterly servicer performance and allocations reports (Federal Student Aid, 2017) beginning in 3rd quarter 2014 and are weighted by servicer by federal loans serviced as of 2018 shown in Table 1. The graph shows correlations between percent of borrowers in repayment that are fewer than six days delinquent and borrower survey and federal personnel survey scores. 


\section{Appendix Figure A6: Relationship Between Metrics, by Servicer}

(A) Current/Borrower Survey, TIVAS

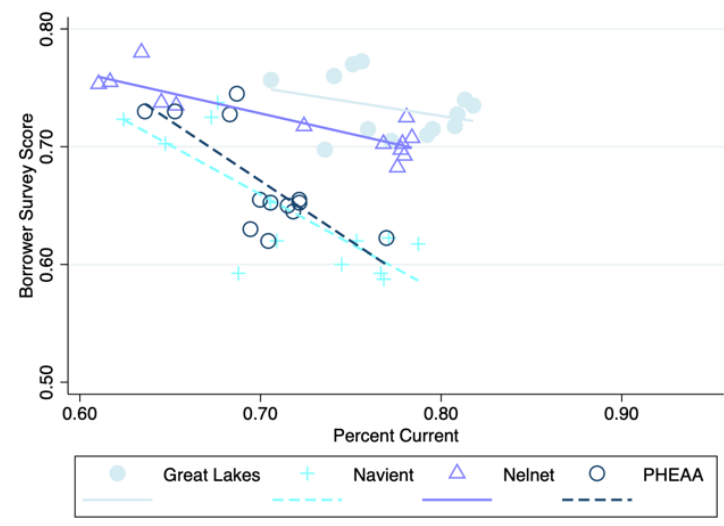

(B) Current/Federal Survey, TIVAS

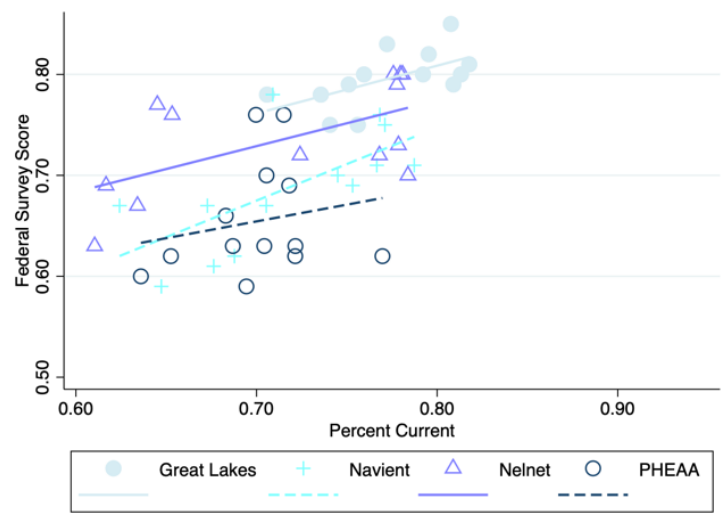

(C) Current/Borrower Survey, NFP

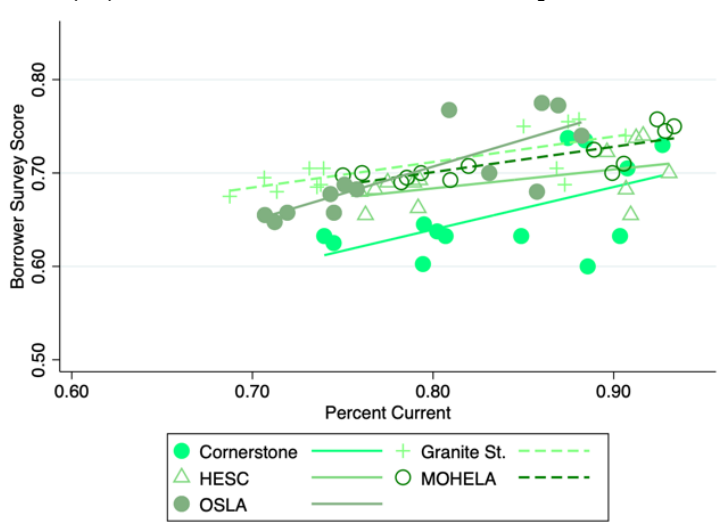

(D) Current/Federal Survey, NFP

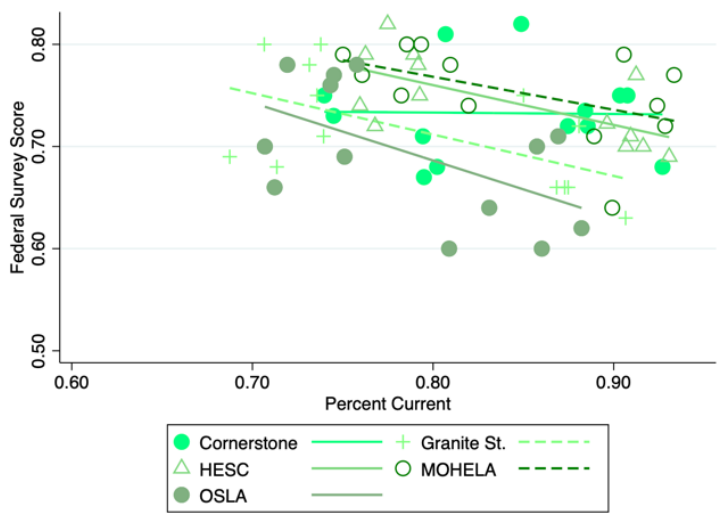

Notes: Data come from Federal Student Aid quarterly servicer performance and allocations reports (Federal Student Aid, 2017), split by servicer, by quarter beginning in 3rd quarter 2014. The graphs show correlations between percent of borrowers in repayment that are fewer than six days delinquent and borrower survey and federal personnel survey scores. 


\section{Appendix Figure A7: Trends in Servicer Complaints - All Complaints}

(A) Overall

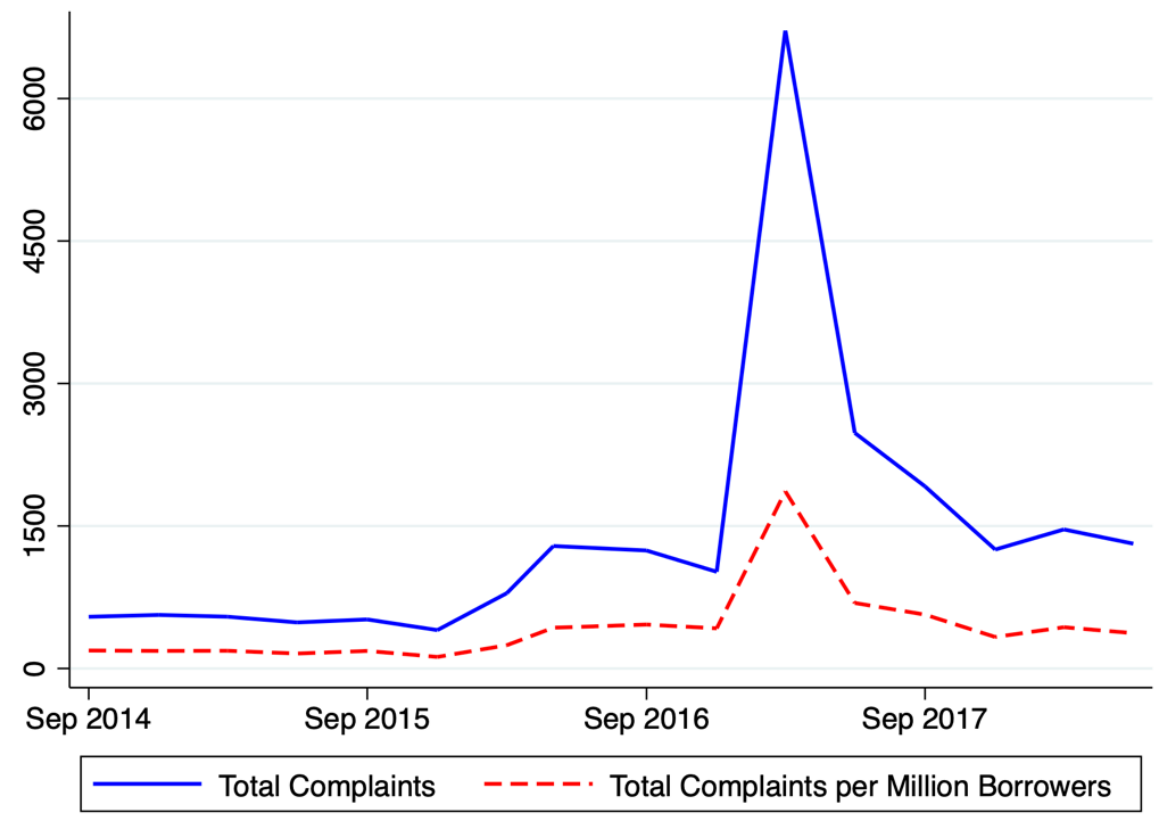

(B) Navient Separate from Other Servicers

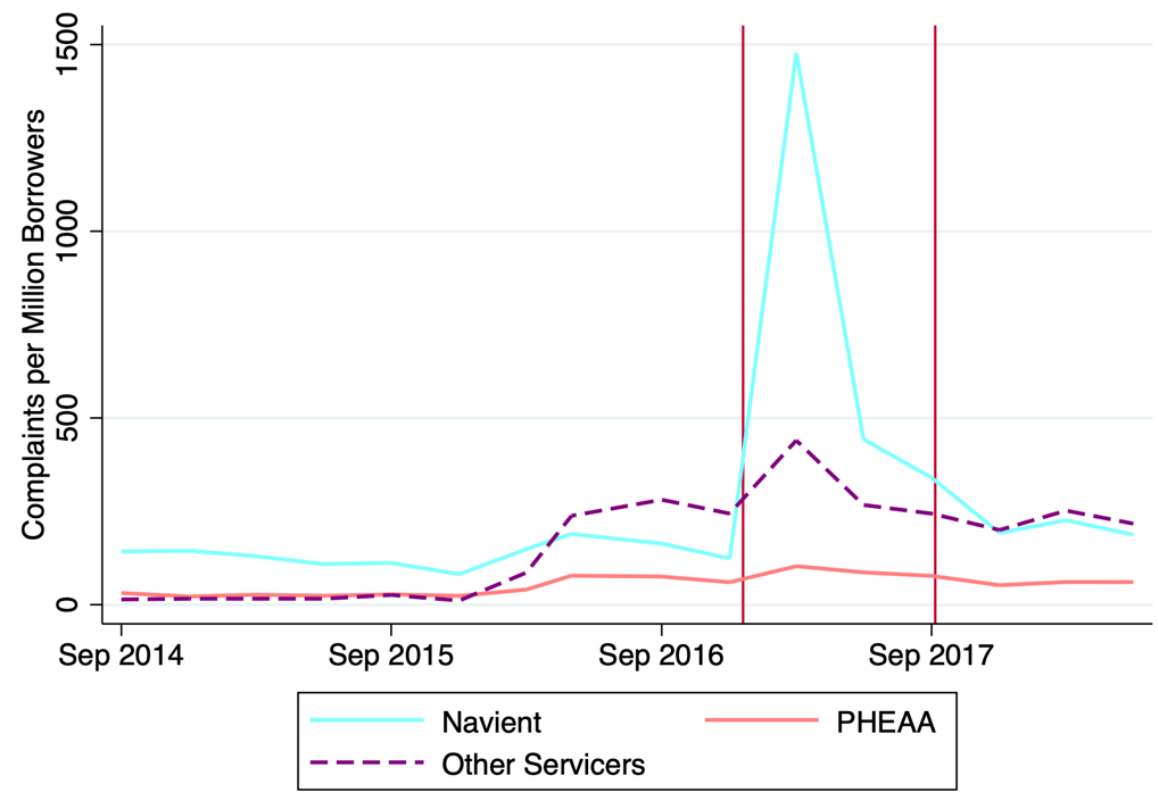

Note: Red lines represent dates lawsuits filed

Notes: Data come from the Consumer Finance Protection Bureau complaint database, starting from September 2014 through June 2018. Vertical red lines are lawsuits filed by state attorney generals against Navient in January and October 2017, respectively. Complaints include those with a subproduct of federal, non-federal, or private loan. 


\section{Appendix Figure A8: Trends in Complaint Category Shares - All Student Loan Complaints}

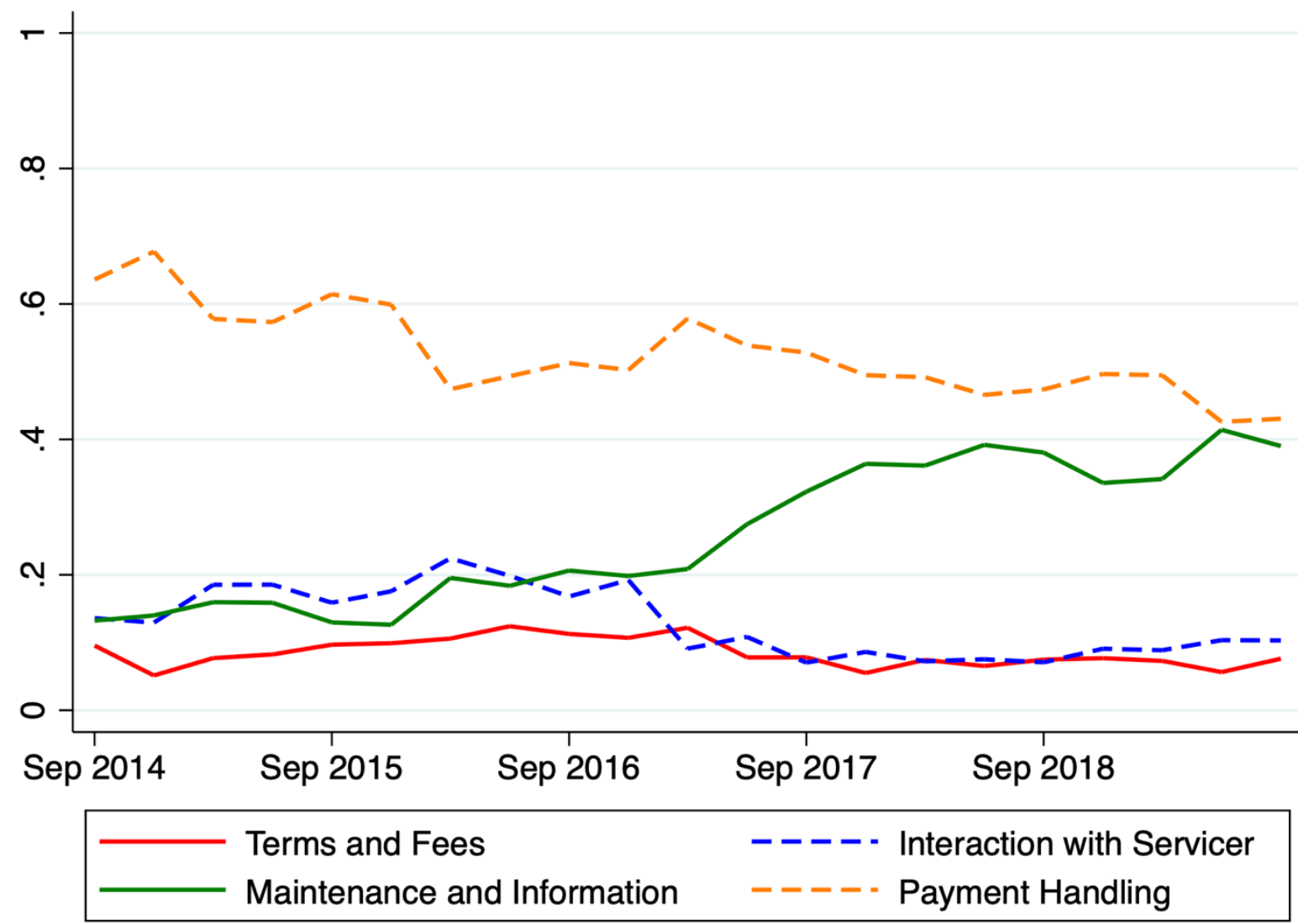

Notes: Data come from the Consumer Finance Protection Bureau complaint database, starting from September 2014 through July 2019. Figure shows trends by quarter of percent of complaints for all servicers by terms and fees, handling payments, interactions with servicers and marketing, or account maintenance and information. Complaints include those with a subproduct of federal, non-federal, or private loan. 
APPENDIX B: Historical Servicer Compensation per Borrower

(A) Compensation Rates from Example Original TIVAS Contract — 2009

\begin{tabular}{|l|c|c|r|}
\hline \multicolumn{1}{|c|}{ Status } & $\begin{array}{c}\text { Volume } \\
\text { Low }\end{array}$ & $\begin{array}{c}\text { Volume } \\
\text { High }\end{array}$ & $\begin{array}{c}\text { Unit Price } \\
(\$)\end{array}$ \\
\hline Borrowers in In-school Status & $\mathrm{N} / \mathrm{A}$ & $\mathrm{N} / \mathrm{A}$ & 1.05 \\
\hline Borrowers in Grace or Current Repayment Status & 1 & $3,000,000$ & 2.11 \\
\hline & $3,000,001$ & $\mathrm{UP}$ & 1.90 \\
\hline Borrowers in Deferment or Forbearance & 1 & $1,600,000$ & 2.07 \\
\hline & $1,600,001$ & $\mathrm{UP}$ & 1.73 \\
\hline Borrowers 31-90 Days Delinquent & $\mathrm{N} / \mathrm{A}$ & $\mathrm{N} / \mathrm{A}$ & 1.62 \\
\hline Borrowers 91-150 Days Delinquent & $\mathrm{N} / \mathrm{A}$ & $\mathrm{N} / \mathrm{A}$ & 1.50 \\
\hline Borrowers 151-270 Days Delinquent & $\mathrm{N} / \mathrm{A}$ & $\mathrm{N} / \mathrm{A}$ & 1.37 \\
\hline Borrowers 270+ Days Delinquent & $\mathrm{N} / \mathrm{A}$ & $\mathrm{N} / \mathrm{A}$ & 0.50 \\
\hline
\end{tabular}

Note: From Sallie Mae 2009 contract.

(B) Compensation Rates from Example Original NFP Contract — 2011

For first 100,000 allocated borrower accounts only, the following pricing shall apply:

\begin{tabular}{|l|l|l|l|}
\hline Category & Unit Price & Min. Order & Max. Order \\
\hline Borrowers in In-school Status & $\$ 1.15$ & 1 & 10 million \\
\hline $\begin{array}{l}\text { Borrowers in Grace or Current Repayment } \\
\text { Status }\end{array}$ & $\$ 2.32$ & 1 & 10 million \\
\hline Borrowers in Deferment or Forbearance & $\$ 2.28$ & 1 & 10 million \\
\hline Borrowers 31-90 Days Delinquent & $\$ 1.78$ & 1 & 10 million \\
\hline Borrowers 91-150 Days Delinquent & $\$ 1.65$ & 1 & 10 million \\
\hline Borrowers 151-270 Days Delinquent & $\$ 1.51$ & 1 & 10 million \\
\hline Borrowers 270+ Days Delinquent & $\$ 0.55$ & 1 & 10 million \\
\hline $\begin{array}{l}\text { On-System Conversion Fees (Per Borrower } \\
\text { Account)* }\end{array}$ & $\$ 10,000$ & 1 & 10 million \\
\hline Incurred Start-Up Costs (per Entity)** & Up to \$300,000 & 1 & 10 million \\
\hline
\end{tabular}

*Applies to the first 100,000 borrower accounts each entity loads onto its system for servicing. Billable only after actual conversion of accounts has occurred. No costs for off-system conversions/transfers shall apply.

**Reimbursable ceiling amount for actual, reasonable, allowable, and allocable costs incurred in meeting the Government's stated requirements, in accordance with FAR 31.201. All costs under this category shall be subject to audit and are only reimbursable after contract award. 
For all borrower accounts above the first 100,000 allocated accounts, the following pricing shall apply:

\begin{tabular}{|l|l|l|l|l|l|}
\hline Category & $\begin{array}{l}\text { Volume } \\
\text { Low }\end{array}$ & $\begin{array}{l}\text { Volume } \\
\text { High }\end{array}$ & Unit Price & $\begin{array}{l}\text { Min. } \\
\text { Order }\end{array}$ & Max. Order \\
\hline Borrowers in In-school Status & N/A & N/A & $\$ 1.05$ & 1 & 10 million \\
\hline $\begin{array}{l}\text { Borrowers in Grace or Current } \\
\text { Repayment Status }\end{array}$ & 1 & $3,000,000$ & $\$ 2.11$ & 1 & 10 million \\
\hline & $3,000,001$ & UP & $\$ 1.90$ & 1 & 10 million \\
\hline $\begin{array}{l}\text { Borrowers in Deferment or } \\
\text { Forbearance }\end{array}$ & 1 & $1,600,000$ & $\$ 2.07$ & 1 & 10 million \\
\hline & $1,600,001$ & UP & $\$ 1.73$ & 1 & 10 million \\
\hline Borrowers 31-90 Days Delinquent & N/A & N/A & $\$ 1.62$ & 1 & 10 million \\
\hline Borrowers 91-150 Days Delinquent & N/A & N/A & $\$ 1.50$ & 1 & 10 million \\
\hline Borrowers 151-270 Days Delinquent & N/A & N/A & 1.37 & 1 & 10 million \\
\hline Borrowers 270+ Days Delinquent & N/A & N/A & 0.50 & 1 & 10 million \\
\hline
\end{tabular}

Note: From MOHELA 2011 Contract.

(C) Compensation Rates from Example Current Servicing Contracts — 2014

\begin{tabular}{|c|c|c|c|c|}
\hline CLIN & Status & Unit & $\begin{array}{c}\text { Unit } \\
\text { Measure }\end{array}$ & Unit Rate \\
\hline 0001 & In School & $1+$ & EA & $\$ 1.05$ \\
\hline 0002 & In Grace & $1+$ & EA & $\$ 1.68$ \\
\hline 0003 & In Repayment & $1+$ & EA & $\$ 2.85$ \\
\hline 0004 & Service Member & $1+$ & EA & $\$ 2.85$ \\
\hline 0005 & Deferment & $1+$ & EA & $\$ 1.68$ \\
\hline 0006 & Forbearance & $1+$ & EA & $\$ 1.05$ \\
\hline 0007 & Delinquent 6-30 Days & $1+$ & EA & $\$ 2.11$ \\
\hline 0008 & Delinquent 31-90 Days & $1+$ & EA & $\$ 1.46$ \\
\hline 0009 & Delinquent $91-150$ Days & $1+$ & EA & $\$ 1.35$ \\
\hline 0010 & Delinquent 151-270 Days & $1+$ & EA & $\$ 1.23$ \\
\hline 0011 & Delinquent 271-360 Days & $1+$ & EA & $\$ 0.45$ \\
\hline 0012 & Delinquent 361 or more Days & $1+$ & EA & S0.45 \\
\hline 0013 & Delinquency Reduction Compensation Program & N/A & N/A & $\begin{array}{c}\text { Not-to-Exceed } \\
\$ 2,000,000\end{array}$ \\
\hline & Cohort Default Rate (CDR) Challenge Support & & & \\
\hline 0014 & Institution $^{2}$ & $1+$ & EA & $\$ 213.00$ \\
\hline 0015 & Borrower $^{3}$ & $1+$ & EA & $\$ 23.00$ \\
\hline & Loan Consolidation & & & \\
\hline 0016 & One-Time Development Cost $t^{+}$ & N/A & N/A & $\begin{array}{l}\text { Not-to-Exceed } \\
\$ 1,200,000.00 \\
\end{array}$ \\
\hline 0017 & Consolidations Completed & $1+$ & EA & $\$ 27.35$ \\
\hline 0018 & CDR Assistance Pilot (rate per school assisted) ${ }^{5}$ & $1+$ & EA & $\$ 18,000.00$ \\
\hline
\end{tabular}

Note: From Navient 2014 contract. 
APPENDIX C: Allocation Measures and Weights

Table C1: Further Detail on Allocation Measures and Weights, 2016-present

\begin{tabular}{|c|c|c|c|c|c|}
\hline Category & $\begin{array}{l}\text { Category } \\
\text { Weight }\end{array}$ & Metric & Metric Weight & Segment (w) & $\begin{array}{l}\text { Segment } \\
\text { Weight } \\
\left(\omega_{w t}\right)\end{array}$ \\
\hline \multirow{15}{*}{ Repayment Status } & \multirow{15}{*}{$60 \%$} & \multirow{5}{*}{$\%$ Current } & \multirow{5}{*}{$30 \%$} & $\begin{array}{c}\text { Consolidation/ } \\
\text { Parent PLUS loan } \\
\text { holders } \\
\end{array}$ & $4.28 \%$ \\
\hline & & & & $\begin{array}{c}\text { Graduated } \leq 3 \\
\text { years }\end{array}$ & $8.57 \%$ \\
\hline & & & & $\begin{array}{c}\text { Graduated }>3 \\
\text { years }\end{array}$ & $8.57 \%$ \\
\hline & & & & $\begin{array}{l}\text { Did not Graduate, } \\
\text { Left school } \leq 3 \\
\text { years }\end{array}$ & $4.30 \%$ \\
\hline & & & & $\begin{array}{l}\text { Did not Graduate, } \\
\text { Left school }>3 \\
\text { years }\end{array}$ & $4.30 \%$ \\
\hline & & \multirow{5}{*}{$\begin{array}{l}\text { \% 91-270 Days } \\
\text { Delinquent }\end{array}$} & \multirow{5}{*}{$15 \%$} & $\begin{array}{c}\text { Consolidation/ } \\
\text { Parent PLUS loan } \\
\text { holders } \\
\end{array}$ & $2.14 \%$ \\
\hline & & & & $\begin{array}{c}\text { Graduated } \leq 3 \\
\text { years }\end{array}$ & $2.70 \%$ \\
\hline & & & & $\begin{array}{c}\text { Graduated }>3 \\
\text { years }\end{array}$ & $2.70 \%$ \\
\hline & & & & $\begin{array}{c}\text { Did not Graduate, } \\
\text { Left school } \leq 3 \\
\text { years }\end{array}$ & $3.73 \%$ \\
\hline & & & & $\begin{array}{c}\text { Did not Graduate, } \\
\text { Left school }>3 \\
\text { years }\end{array}$ & $3.73 \%$ \\
\hline & & \multirow{5}{*}{$\begin{array}{l}\text { \% 271-360 Days } \\
\text { Delinquent }\end{array}$} & \multirow{5}{*}{$15 \%$} & $\begin{array}{c}\text { Consolidation/ } \\
\text { Parent PLUS loan } \\
\text { holders }\end{array}$ & $2.14 \%$ \\
\hline & & & & $\begin{array}{c}\text { Graduated } \leq 3 \\
\text { years }\end{array}$ & $2.46 \%$ \\
\hline & & & & $\begin{array}{c}\text { Graduated }>3 \\
\text { years }\end{array}$ & $2.46 \%$ \\
\hline & & & & $\begin{array}{c}\text { Did not Graduate, } \\
\text { Left school } \leq 3 \\
\text { years }\end{array}$ & $3.97 \%$ \\
\hline & & & & $\begin{array}{c}\text { Did not Graduate, } \\
\text { Left school }>3 \\
\text { years }\end{array}$ & $3.97 \%$ \\
\hline \multirow{4}{*}{$\begin{array}{l}\text { Borrower } \\
\text { Satisfaction }\end{array}$} & \multirow{4}{*}{$35 \%$} & \multirow{4}{*}{ Borrower Survey } & & In School & $8.75 \%$ \\
\hline & & & & In Grace & $8.75 \%$ \\
\hline & & & & $\begin{array}{c}\text { In Repayment, } \\
\text { Current }\end{array}$ & $8.75 \%$ \\
\hline & & & & $\begin{array}{c}\text { In Repayment, } \\
\text { Delinquent }\end{array}$ & $8.75 \%$ \\
\hline
\end{tabular}




\begin{tabular}{|c|c|c|c|c|c|}
\hline $\begin{array}{c}\text { Federal Personnel } \\
\text { Satisfaction }\end{array}$ & $5 \%$ & $\begin{array}{c}\text { Survey of FSA } \\
\text { Personnel }\end{array}$ & N/A & $5 \%$ \\
\hline
\end{tabular}

To create the weights $\omega_{w t}$ in the previous table, servicer performance is first weighted by the number of borrowers in repayment of that segment, $w$, such as graduated in past three years and current, across all servicers, $j,\left(W \Phi_{j w t}=\Phi_{j w t} * \frac{N_{w t}}{N_{t}}\right)$. FSA next multiplies the weighted points by a "Delinquency Adjustment Factor" $\left(D A F=\frac{\# \text { Delinquent }_{w, t}}{\# \text { In Repayment }}{ }_{w, t} / \frac{\# \text { Delinquent }_{t}}{\# \text { In } \text { Repayment }_{t}}\right)$ for each segment, which is percent of borrowers delinquent in that segment relative to the overall delinquency rate, making segments with a high delinquency rate given more points. As allocations are determined semiannually, but performance is measured quarterly, delinquency-adjusted points are then averaged across the two quarters. For each of the three delinquency metrics, percent current, percent 91-270 days delinquent, and percent 271-360 days delinquent, servicers are then ranked from highest to lowest based on average delinquency adjusted points across each segment in that state, with the best again receiving $\Phi$ points, the second best $\Phi-1$ points, and so on, where $\Phi$ is the number of servicers. Last, a servicer's points are multiplied by that state's weight (30\%, $15 \%$, and $15 \%$ for current, moderately delinquent, and severely delinquent, respectively). $\omega_{w t}$ come from estimated weights in Table E1 $\omega_{s t}$ multiplied by the metric's weight. 
Table C2: Historical Allocation Metrics

\begin{tabular}{|c|c|c|c|c|c|c|c|c|}
\hline & \multicolumn{4}{|c|}{$\frac{\text { Original TIVAS Allocation Weights }}{(2010-2014)}$} & \multicolumn{4}{|c|}{$\frac{\text { Current Servicer Allocation Weights }}{(2014-2019)}$} \\
\hline & $\begin{array}{l}\text { Category } \\
\text { Weight }\end{array}$ & Metric & Segment & Weight & $\begin{array}{l}\text { Category } \\
\text { Weight }\end{array}$ & Metric & Segment & Weight \\
\hline \multirow{6}{*}{$\begin{array}{l}\text { Default } \\
\text { Prevention }\end{array}$} & \multirow{6}{*}{$40 \%$} & \multirow{3}{*}{$\begin{array}{l}\text { "In } \\
\text { Repayment" } \\
\text { Portfolio } \\
\text { Dollars that } \\
\text { go into } \\
\text { default }\end{array}$} & $\begin{array}{l}\text { Public } \\
\text { School }\end{array}$ & $6.67 \%$ & \multirow{6}{*}{$60 \%$} & \multirow{2}{*}{$\%$ Current } & \multirow{2}{*}{ N/A } & \multirow{2}{*}{$30 \%$} \\
\hline & & & $\begin{array}{l}\text { Private } \\
\text { Schools }\end{array}$ & $6.67 \%$ & & & & \\
\hline & & & $\begin{array}{l}\text { Proprietary } \\
\text { Schools }\end{array}$ & $6.67 \%$ & & \multirow{2}{*}{$\begin{array}{c}\% 91-270 \\
\text { Days } \\
\text { Delinquent }\end{array}$} & \multirow{2}{*}{ N/A } & \multirow{2}{*}{$15 \%$} \\
\hline & & \multirow{3}{*}{$\begin{array}{l}\text { "In } \\
\text { Repayment" } \\
\text { Portfolio } \\
\text { borrowers } \\
\text { that go into } \\
\text { default }\end{array}$} & $\begin{array}{l}\text { Public } \\
\text { Schools }\end{array}$ & $6.67 \%$ & & & & \\
\hline & & & $\begin{array}{l}\text { Private } \\
\text { Schools }\end{array}$ & $6.67 \%$ & & \multirow{2}{*}{$\begin{array}{c}\% \text { 271-360 } \\
\text { Days } \\
\text { Delinquent }\end{array}$} & \multirow[t]{2}{*}{ N/A } & \multirow[t]{2}{*}{$15 \%$} \\
\hline & & & $\begin{array}{l}\text { Proprietary } \\
\text { Schools }\end{array}$ & $6.67 \%$ & & & & \\
\hline \multirow{4}{*}{$\begin{array}{l}\text { Borrower } \\
\text { Satisfaction }\end{array}$} & \multirow{4}{*}{$20 \%$} & \multirow{4}{*}{$\begin{array}{l}\text { Borrower } \\
\text { Survey }\end{array}$} & In School & $6.67 \%$ & \multirow{4}{*}{$35 \%$} & \multirow{4}{*}{$\begin{array}{l}\text { Borrower } \\
\text { Survey }\end{array}$} & In School & $8.75 \%$ \\
\hline & & & & & & & In Grace & $8.75 \%$ \\
\hline & & & In Grace & $6.67 \%$ & & & $\begin{array}{c}\text { In } \\
\text { Repayment, } \\
\text { Current }\end{array}$ & $8.75 \%$ \\
\hline & & & $\begin{array}{c}\text { In } \\
\text { Repayment }\end{array}$ & $6.67 \%$ & & & $\begin{array}{c}\text { In } \\
\text { Repayment, } \\
\text { Delinquent }\end{array}$ & $8.75 \%$ \\
\hline \multirow{3}{*}{$\begin{array}{c}\text { School } \\
\text { Satisfaction }\end{array}$} & \multirow{3}{*}{$20 \%$} & \multirow{3}{*}{$\begin{array}{l}\text { School } \\
\text { Surveys }\end{array}$} & $\begin{array}{l}\text { Public } \\
\text { Schools }\end{array}$ & $6.67 \%$ & \multirow{3}{*}{$0 \%$} & \multirow{3}{*}{ N/A } & \multirow{3}{*}{ N/A } & \multirow{3}{*}{$0 \%$} \\
\hline & & & $\begin{array}{l}\text { Private } \\
\text { Schools }\end{array}$ & $6.67 \%$ & & & & \\
\hline & & & $\begin{array}{l}\text { Proprietary } \\
\text { Schools }\end{array}$ & $6.67 \%$ & & & & \\
\hline $\begin{array}{c}\text { Federal } \\
\text { Satisfaction }\end{array}$ & $20 \%$ & $\begin{array}{l}\text { Survey of } \\
\text { FSA } \\
\text { Personnel }\end{array}$ & N/A & $20 \%$ & $5 \%$ & $\begin{array}{c}\text { Survey of } \\
\text { FSA } \\
\text { Personnel }\end{array}$ & N/A & $5 \%$ \\
\hline
\end{tabular}

Notes: Metrics and weights come from Federal Student Aid's "Explanation of Allocation and Performance Measure Methodology" (Federal Student Aid, 2015). Subparts for the "repayment status" goal are weighted based on percentage of all borrowers in repayment in that segment, and the segment's delinquency rate. Given these changes over time, subpart weights change over time and are not shown. Weights for repayment status subparts are based on estimates described in detail in Appendix E. 
Until Q3 2014, FSA awarded servicers new portfolios each July based on average quarterly performance of the year prior, similar to the current system although different metrics. There were four main categories, detailed in Table C2: repayment status/default prevention, borrower satisfaction, school satisfaction, and federal personnel satisfaction. All metrics except federal satisfaction were split into segments, such as percent of loans in repayment that go into default for students at public schools. Each segment was given a score with the best ranking servicer receiving the points equal to the number of servicers, the second-best given points equal to the number of servicers minus one, and so on, with the servicer with the worst performance in the segment receiving one point. For each servicer, segment scores in each metric were averaged together to create a metric score. For example, a servicer's scores for the borrower surveys for in school, in grace, and in repayment would be averaged together to make the metric score for the borrower survey. Metric scores were then multiplied by its given weight and added together. The allocation for a servicer was equal to the number of points it had, divided by total points held by all servicers (Federal Student Aid, 2009). ${ }^{16}$

\footnotetext{
${ }^{16}$ For example, if there were five servicers, the number of total points would be 75 . First, as there are five metrics and five servicers, 15 points would be given for each metric ( 5 for first, 4 for second, etc.). Then, as there are five metrics, each with 15 points distributed, the total points given would be 75 ( 15 points per metric multiplied by 5 metrics). The servicer's percentage of allocation of new borrower would then be its points (maximum of 25 and minimum of five) divided by 75 .
} 


\section{Appendix D: CFPB Issue Coding}

After exporting data with the product label student loan, January 2016 through July 2019, and only keeping servicers of interest in this paper, we are left with 24,793 complaints. We choose the start date of January 2016, as CFPB did not separately track federal student loan servicing, previously focusing on private student loan servicing (Delisle and West, 2019). Within the CFPB complaint database, complaints are labeled by standardized subissues. Complaints in our data take one of 48 subissues. In coding issues as by category, we assigned subissues based on the core problem. Table D1 lists the issues, category, and their frequency. All includes complaints with a subproduct listing of either federal, non-federal, or private student loan servicing, with the right-most column limiting frequencies to only complaints with a subproduct of federal student loan servicing. 
Table D1: Frequency of Subissues by Category

\begin{tabular}{|c|c|c|}
\hline Subissue & $\begin{array}{l}\text { Frequency: } \\
\text { All }\end{array}$ & $\begin{array}{l}\text { Frequency: } \\
\text { Federal Only }\end{array}$ \\
\hline \multicolumn{3}{|l|}{ Account Maintenance and Information } \\
\hline Received bad information about my/your loan & 4,928 & 3,732 \\
\hline Need information about my/your loan balance/terms & 1,006 & 689 \\
\hline Account information/status incorrect ${ }^{\wedge}$ & 577 & 461 \\
\hline Their investigation did not fix an error on your report & 145 & 128 \\
\hline Fraudulent loan & 92 & 0 \\
\hline Information belongs to someone else & 67 & 49 \\
\hline Old information reappears or never goes away & 57 & 48 \\
\hline Problem with personal statement of dispute & 33 & 30 \\
\hline Billing dispute for services & 27 & 24 \\
\hline Reporting company used your report improperly & 20 & 16 \\
\hline Personal information incorrect & 10 & 8 \\
\hline Investigation took more than 30 days & 10 & 7 \\
\hline Other problem getting your report or credit score & 9 & 8 \\
\hline Was not notified of investigation status or results & 8 & 8 \\
\hline Information is missing that should be on the report & 7 & 7 \\
\hline Credit inquiries on your report that you don't recognize & 4 & 4 \\
\hline Public record information inaccurate & 4 & 4 \\
\hline Report provided to employer without your written authorization & 2 & 2 \\
\hline Problem cancelling credit monitoring or identity theft protection services & 1 & 1 \\
\hline Problem with signing the paperwork & 1 & 0 \\
\hline \multicolumn{3}{|l|}{ Handling Payments } \\
\hline Trouble with how payments are handled ${ }^{\wedge}$ & 5,301 & 3,682 \\
\hline Can't decrease my/Problem lowering your monthly payments & 3,271 & 1,839 \\
\hline Can't get flexible payment options for repaying your loan & 3,242 & 1,935 \\
\hline Can’t temporarily delay/postpone making payments ${ }^{\wedge}$ & 1,032 & 571 \\
\hline \multicolumn{3}{|l|}{ Terms and Fees } \\
\hline Don’t agree with fees charged ${ }^{\wedge}$ & 2,198 & 1,522 \\
\hline Can't qualify for a loan & 44 & 1 \\
\hline Qualified for a better loan than the one offered ${ }^{\wedge}$ & 29 & 0 \\
\hline Problem with the interest rate & 9 & 0 \\
\hline Denied loan & 8 & 0 \\
\hline Problem with product or service terms changing & 5 & 4 \\
\hline \multicolumn{3}{|l|}{ Interaction with Servicer and Marketing } \\
\hline Problem with customer service & 1,869 & 1,271 \\
\hline Keep getting calls about my/your loans ${ }^{\wedge}$ & 696 & 335 \\
\hline Confusing or misleading advertising & 42 & 0 \\
\hline $\begin{array}{l}\text { Difficulty submitting a dispute or getting information about a dispute } \\
\text { over the phone }\end{array}$ & 25 & 20 \\
\hline Received unwanted marketing or advertising & 4 & 4 \\
\hline Didn't receive services that were advertised & 4 & 3 \\
\hline
\end{tabular}

Notes: ^ indicates subissue frequency combined with another extremely similar subissue, where issues could be combined without losing meaning. For example, one was "Received bad information about my loan" and another "Received bad information about your loan," which we combined into "Received bad information about my/your 
loan." Subissues had slight changes like the above example over the time period of complaints, January 2016 through July 2019.

Borrowers making complaints through CFPB are given the option to write a narrative about the complaint. Below are examples from chosen subissues to help provide rationale behind our coding.

\section{Examples of "Don't Agree with fees charged"}

I took classes via a method I didn't understand in 2014. It was a vet difficult, online college program prepared by $X X X X$ University. When classes were dropped, loans were not rebuked by financial aid and I think this is wrong. I am $\{\$ 5000.00\}$ in debt and I only passed XXXX classes - I also only saw XXXX classes through. I don't understand why I am not merely paying for those $X X X X$ classes and the loans granted for them. What is the reason I have to pay for student loans for classes I did not complete? Loan is financed by Great Lakes. I had no understanding of loans and no family I could discuss them with but I believe that if I quick the class in time it isn't fair that I was still charged for loans that I never saw the light on. 8/23/16 Great Lakes

I applied to $X X X X$ in $X X / X X / X X X X$, graduated with an $X X X X$ in $X X / X X / X X X X$ and wanted to pursue my $X X X X$ in $X X / X X / X X X X$ continuing my knowledge in the same field. Unfortunately, all of $X X X X$ got shut down due to fraud and when I tried to continue with my credentials, that I supposedly received already from $X X X X$, the new institution ( $X X X X$ ) told me no one will be accepting any transfers or credits from XXXX. I am now responsible for a Federal Student Loan through Great Lakes Borrowers and I don't feel I should be responsible to pay back anything due to XXXX going bankrupt and making promises they never fulfilled also for wasting my time in pursuance of a career that has no credential back up. 3/28/17 Great Lakes

I decided to quit attending XXXX after seeing the teachers not help but actually give the answers away for the tests so everyone would pass. Upon seeing this I knew the degree from XXXX would be worthless. This would hurt any chance I had of getting a job in the field of study I was in. 1/19/17 Navient

When I signed up for $X X X X$ I was under that this was the best career to go into. They did not explain that I would end up paying over XXXX. I did not understand the interest on the balance. 1/19/17 Navient

\section{Examples of "Trouble with how payments are handled"}

I have called GSMR multiple times over the last year regarding my loan payments. I have been enrolled in autopay for a number of years and noticed in $X X / X X / X X X X$ my payments stopped being collected for no apparent reason. I was informed by GSMR that this was because I entered a graduate program and the loans were in deferment. I requested that my loans not be placed in deferment, and that I wished to continue making payments on my account. I was informed by a customer service representative that I would occasionally miss one month, as their process was automatic, but there were notes made on my account and the autopay would pick up the following month. Whereas I didn't fully approve of this explanation, I went with it as I didn't feel like fighting. 
I notice today that apparently they have not pulled a payment since $X X / X X / X X X X$. I feel this is an unethical business practice, as they cancel my autopay, with no notice to me, and continue to rack up interest on a loan that I have been attempting to pay. This organization makes it so difficult to repay your loan in hopes that they can continue to collect interest from you. 1/12/18 Granite State

Nelnet, my loan servicer, has been actively preventing my payments from going through the way I want them to. I have had special standing instructions for my auto-debit to apply all extra funds to the loan with the highest interest rate, but this is the second time they 've been " misplaced" after my payment goes through. I have no way of viewing these instructions or verifying that they're being followed until way after I make my payment without calling Nelnet. Access to the proper information is buried way too deeply on the site. They keep using their own way of applying funds where they " catch up " my lower interest loans to where my higher interest one is in my payment schedule, then I have to spend about 1-2 hours every single month correcting the problem with them. Their website does not show any of this information. 1/23/17 Nelnet

\section{Examples of "Can't get flexible payment options for repaying your loan"}

I obtained about $X X X X$ in student loan debt $X X / X X / X X X X$. When I graduated from college $X X / X X / X X X X, I$ wasn't able to pay back my loan at the minimum payment because of other debt. They wouldn't allow me to use an income-based payment plan because that only calculated my income and not any of my bills. Not being able to make the payment they always suggested that I do a forebearance which continued to accrue interest. When I finally had the opportunity to consolidate my loans, the lowest rate was $8.25 \%$. My debt is now XXXX and I pay $8.25 \%$ interest on it. I'm not allowed to re-consolidate at a lower rate so I'm stuck with this high interest debt of $X X X X$. I've been making monthly payments for a few years but I can only pay $\$ X X X X /$ month because of other income obligations. This doesn't even cover my interest. I will be paying for this loan for the rest of my life with no opportunity to re-consolidate at a lower rate and the principal payoff increases every month. If I was able to use the income based repayment plan and have it factor in my bills vs my income, I probably could have made payments rather than forbearance. They made the forbearance option way too easy. 1/21/17 MOHELA

I feel we were mislead with the forbearance. The interest that accrued over the course of forbearance is close to $\{\$ 20000.00\}$ in 5 years. The original loan was $\{\$ 58000.00\}$. We did not fully understand this process. During this time, we went through a bankruptcy. This is our daughter's student loan taken out as a parent loan. We also did not realize she was not on the loan at all as the plan was for her to pay her loan. She worked in low income schools as a XXXX and was not able to get the loan discounted as it was in our names only. We would have done the original loan as a cosigner if we had been offered that option. Our complaint is with the servicer both XXXX and Navient. The school attended was XXXX. 2/19/17 Navient

I've had to defer and place my loans in forebearance ever since graduating and thanks to the interest rate, I may never pay it down. I'm grateful for the loan but need help getting the balance down or possibly lowered interest rates. I was able to get an income based repayment but it expires this year and my cost is increasing monthly. 1/21/17 Navient 


\section{Appendix E: Data \& Estimation of Servicer Semiannual Allocations}

\section{Data}

Data come from Federal Student Aid (FSA) quarterly Servicer Performance and Allocations reports. Each quarter, FSA publishes a report within its online Data Center (https://studentaid.ed.gov/sa/about/data-center/business-info/contracts/loan-servicing/servicerperformance\#Reports $\% 20 \mathrm{by} \% 20$ Quarter) of each servicer's performance in each metric. For repayment, this is the repayment rate during the quarter, by delinquency, within each segment. For the borrower and federal personnel surveys, it is the average score. Allocations by servicer as a percent of total are also published for Q2 and Q4 each year. Explanations of the performance and allocation methodology accompany each quarterly report. Data on number of borrowers by servicer, loan status, and quarter also come from the FSA "Data Center" (Federal Student Aid 2018a), https://studentaid.ed.gov/sa/about/data-center/student/portfolio.

There is a lack of detail on some aspects in the data. Specifically, although their splitting repayment rates into five segments since 2016 has added detail about subpopulations, the data do not list what percentage of borrowers for a given servicer falls into each segment. To create a weighting scheme, we use other data for Federal Student Aid to estimate weights. First, we find the percent of borrowers who have a consolidated or Parent PLUS loan, about 14\% across repayment rates. Next, we find data showing the number of borrowers who have a direct loan, split by graduated or not graduated status and days delinquent. As we do not know the number of borrowers by days since left or graduated from school, we split the weight for number of students graduated or not-completed school each halfway. For example, about $57.2 \%$ of borrowers who have paid in the past 90 days and do not have a Consolidated or Parent PLUS are in repayment and graduated from school. We thus assigned a weight of about $28.6 \%$ (half of $57 \%$ ) to both 
segments (2) and (3) within the metric of borrowers paying in the past 90 days. We did this for each segment within each metric. We then use this weighted data for analyzing the relationships between repayment rates and the two surveys.

\section{Estimation of Servicer Semiannual Allocations}

To estimate servicer semiannual allocation, we followed the method in Federal Student Aid's (FSA) "Explanation of Allocation and Performance Measure Methodology" document.

However, while we had the values for each servicer for each quarter of performance by metric and segment, some information was not provided, specifically, the number of borrowers in each segment, which is factored into weighting performance. As the number of borrowers in each segment is used to weight scores, we therefore needed to estimate the number of students in each of the five segments (S) within each metric (M).

Making Segment Weights

$\mathrm{S} 1$ is "Borrowers with at least one Consolidation or Parent PLUS loan." Using Federal Student Aid's data on "Portfolio by Loan Type," the percentage of borrowers fitting S1's criteria has consistently been just over 14 , and we therefore use the weight of $14.25 \%$ across all metrics, the average from 2014 through 2017.The remaining $85.75 \%$ of borrowers are therefore in the remaining segments.

S2 is "Borrowers with no Consolidation or Parent PLUS loans, separation dates 1,094 days or less from the last day of the current quarter, and an enrollment status code of G (graduated)." S3 is the same except it is "separation dates 1,095 days or greater ..." instead.

S4 is "Borrowers with no Consolidation or Parent PLUS loans, separation dates 1,094 days or less from the last day of the current quarter, and without an enrollment status code of G (graduated)." S5 is the same except it is "separation dates 1,095 days or greater ..." instead. 
Another FSA data file, "Direct Loan Portfolio by Delinquency Status and Enrollment" shows the number of borrowers who have Direct Loans, are in repayment status, and how many borrowers are in each delinquency length (e.g., 91-180 days). We then put the number of borrowers into their respective segment dependent on their status (either S2 and S3 or S4 and S5) and delinquency.

We then divided the number of borrowers in that segment and metric by the total number of borrowers in that metric (except the number of borrowers in S1). We then multiplied that percentage by $85.75 \%$, the percentage of borrowers in segments $2,3,4$, or 5 . As we do not know how long they have been in their status of graduating from or leaving school, we do not know how many students are in $\mathrm{S} 2$ versus $\mathrm{S} 3$ or S4 versus S5. We therefore divide the number by two for each segment. Table E1 below shows the weight used for each of the 15 segments and metrics.

\begin{tabular}{|c|c|c|}
\hline \multicolumn{3}{|c|}{ Table E1. Weight for Metric and Segment } \\
\hline Metric & Segment & $\omega_{\text {st }}$ \\
\hline 1 & 1 & 0.1425 \\
\hline 1 & 2 & 0.2855 \\
\hline 1 & 3 & 0.2855 \\
\hline 1 & 4 & 0.1433 \\
\hline 1 & 5 & 0.1433 \\
\hline 2 & 1 & 0.1425 \\
\hline 2 & 2 & 0.1801 \\
\hline 2 & 3 & 0.1801 \\
\hline 2 & 4 & 0.2487 \\
\hline 2 & 5 & 0.2487 \\
\hline 3 & 1 & 0.1425 \\
\hline 3 & 2 & 0.1639 \\
\hline 3 & 3 & 0.1639 \\
\hline 3 & 4 & 0.2649 \\
\hline 3 & 5 & 0.2649 \\
\hline
\end{tabular}




\section{Calculating Allocations}

After creating segment weights, we then followed Federal Student Aid steps in calculating new allocations. We first calculated the base score for each segment.

(1) Calculate Base Score

$$
\Phi_{i, t, m, s}=J_{t}-\operatorname{Rank}_{j, t, m, s}+1,
$$

where $J_{t}$ is the number of servicers in quarter $t, \operatorname{Rank}_{j, t, m, s}$ is the servicer $j$ 's rank in that time period for that metric $m$ for that segment $s$. For Metric 1, percent current, the servicer with highest rate of repayment is ranked 1, whereas for Metrics 2 and 3, percent 91-270 days delinquent and percent 271-360 days delinquent, the servicer with the lowest rate is ranked 1. Doing this for each of the five segments for each of the three repayment metrics creates 15 base scores, which will then be weighted.

(2) Weight Score Based on Number of Borrowers in Each Segment

$$
W \Phi_{j, t, m, s}=\omega_{s t} * \Phi_{j, t, m, s},
$$

where $\omega_{s t}$ refers to the respective weight for each metric's segments shown in Table E1. FSA weights base scores as some segments have more borrowers, so we weight each segment based on our estimated number of borrowers in each metric and segment.

(3) Calculate Score across Two Periods

$$
T w o_{-} P e r i o d \_W \Phi_{j, t, m, s}=\frac{W \Phi_{j, m, s, t}+W \Phi_{j, m, s, t-1}}{2}
$$

As FSA allocates new loans to servicers semiannually, but repayment metrics and scores are calculated quarterly, FSA averages scores, by metric and segment, with the prior time period. We do likewise to create a two-period weighted score for each servicer in each time period, for each metric and segment, shown by equation (3). 
(4) Calculate Base Metric Score by Aggregating Segments to Metric

$P \Phi_{j, t, m}=\sum_{s=1}^{5} T w o_{-} P e r i o d_{-} W \Phi_{j, t, m, s}$.

For each time period and servicer, we then aggregate scores from the segment to the metric level to create a preliminary metric score.

(5) Assign Points based on Metric Score Ranks

$$
\Phi_{j, t, m}=J_{t}-\text { Metric }_{R a n k} \operatorname{Rt}_{, m}+1 .
$$

FSA then assigns points for servicer ranks in each of the five metrics, similar to (1). For each metric, the servicer with the highest $P \Phi_{j, t, m}$ receives a Metric_Rank of one, the second highest a Metric_Rank of two, and so on for each servicer.

(6) Weight Final Metric Points by Weighting Factor

$$
W \Phi_{j, t, m}=\omega_{m} * \Phi_{j, t, m}
$$

We then weight the Metric_Points where weights for each metric are in Table E2 below.

\begin{tabular}{|c|c|}
\hline \multicolumn{2}{|c|}{ Table E2. Metric Weights } \\
\hline Metric & $\omega_{m}$ \\
\hline 1 - Paid in past 90 Days & $30 \%$ \\
\hline 2 - Paid in past 91-270 Days & $15 \%$ \\
\hline 3 - Paid in past 271-360 Days & $15 \%$ \\
\hline $4-$ Borrower Survey & $35 \%$ \\
\hline 5 - Federal Survey & $5 \%$ \\
\hline
\end{tabular}

(7) Aggregate Weighted Metric Points to Overall Score

$$
\Phi_{j, t}=\sum_{m=1}^{5} W \Phi_{j, t, m}
$$


We then calculate an overall performance score for each servicer and time period by aggregating each servicer's weighted metric points.

(8) Aggregate Servicer Overall Scores to Determine Total Period Points

$\Phi_{t}=\sum_{j=1}^{J} \Phi_{j, t}$

We then calculate how many points were allocated overall in each time period by aggregating overall scores for the time period.

(9) Determine Servicer Allocation by Fraction of Total Period Points

$$
\text { New_Allocation }_{j, t}=\frac{\Phi_{j, t}}{\Phi_{t}} .
$$

Last, we find the final estimate of the new allocation percentage for each servicer and time period by dividing its overall score by total points for that time period. 


\section{Appendix F: Brief Federal Student Loan History}

Prior to the federal government's entry into student loans, students who needed to borrow to finance postsecondary education expenses would typically seek funds from private sources, including nongovernmental financial institutions, family and friends, or colleges and universities. These credit constraints had the potential to lead to an underinvestment in human capital (Friedman, 1962). Because the asset financed with a student loan cannot be securitized, there are limited recovery options for the lender in the event of debtor default, making it costly for lenders to lend to prospective students. As well, since research consistently demonstrates that college improves societal welfare beyond private returns to the student (e.g., Avery and Turner, 2012; Card, 1999; Oreopoulos and Salvanes, 2011; Moretti, 2004), high costs of borrowing will lead individuals to attend college at a lower rate than is socially optimal.

The largest federal student loan program, now called Stafford Loans after U.S. Senator Robert T. Stafford, started in 1965 with the passage of the Higher Education Act. Institutional eligibility to disburse student loans to their students depends on meeting a series of requirements related to fiscal health, accreditation, and other policies (see Darolia, 2013. for a discussion of these eligibility policies). Until the early 1990s, private lenders under the Stafford program used their own capital to make student loans to students and their parents and were responsible for collection and servicing. The federal government set the rate of the loans, which were typically below what one would expect to be able to obtain in the private market and set other terms regarding eligibility requirements, borrowing limits, and repayment options. These Federal Family Education Loan (FFEL) program loans were subsidized and guaranteed by the federal government, such that private lenders were insured against default (i.e., the lender was reimbursed if the debtor defaulted). 
In 1994, the government started the William D. Ford Federal Direct Loan Program (Direct Loans), where the government uses federal funds from the U.S. Department of the Treasury to directly lend to students and their families. While the U.S. Treasury provides the funds, the U.S. Department of Education hires private contractors to service and collect the loans. Many of the Direct Loan servicers also contract with private lenders to service loans under the FFEL program. Both FFEL program loans and Direct Loans were available to students and their families through 2010, and terms across programs were nearly identical to the borrower. ${ }^{17}$ However, new loans were discontinued under the FFEL program in 2010 with the passage of the Health Care and Education Reconciliation Act, such that all new Stafford loans since 2010 are funded directly by the government and serviced by private contractors. Prior to its elimination, about $80 \%$ of the federal outstanding student loan debt was from the FFEL program, with most of the remainder coming from the Direct Loan program. ${ }^{18}$ By 2018, that ratio flipped, with Direct Loans comprising approximately $80 \%$ of the portfolio. See Appendix Figure F1, for the trend of the portfolio composition.

\footnotetext{
${ }^{17}$ There were small differences in fees: Under both programs, students were charged a $1 \%$ origination fee, but under direct loans, debtors could get a refund of a portion of their origination fee if they repaid on time. There were also some interest rate differences in some years on loans made to parents of undergraduate students (PLUS loans; these loans were also available to graduate students who exceeded the borrowing limit on Stafford loans).

${ }^{18}$ About $1 \%$ of outstanding loan debt is from the recently retired Perkins Loans program. Perkins Loans were first authorized in 1958 under the National Defense Education Act. Perkins Loan funds are distributed directly to colleges and universities, who allocate funds to their students based on need.
} 


\section{Appendix Figure F1: Federal Student Loan Portfolio, 2007-2018}

(A) Recipients

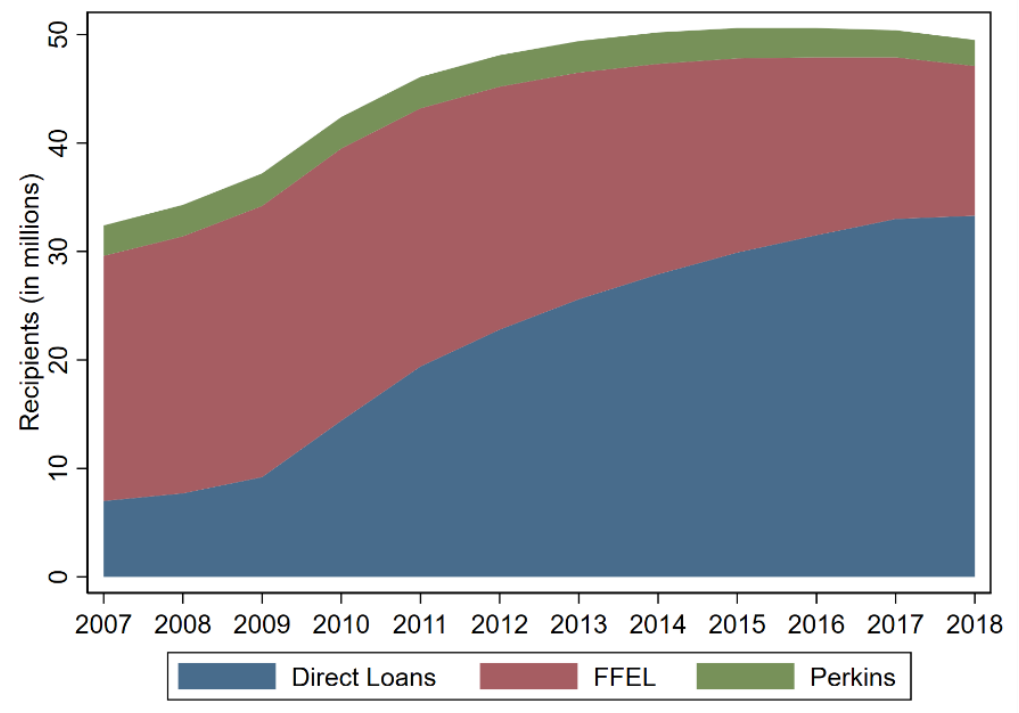

(B) Dollars

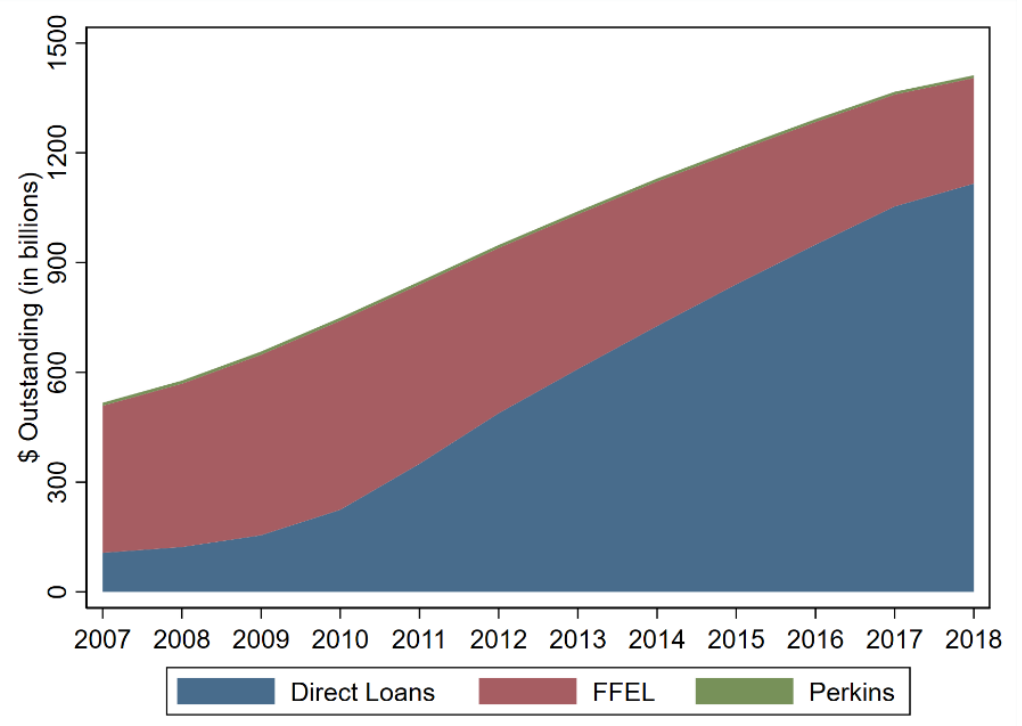

Source: National Student Loan Data System (NSLDS), as reported by the U.S. Department of Education. 


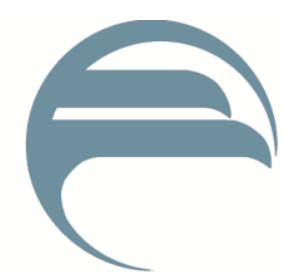

FEDERAL Reserve BANK of PHILADELPHiA

Consumer Finance Institute Discussion Paper Series

http://www.philadelphiafed.org/consumer-finance-institute 